TITLE:

\title{
Synthesis of 3,3-disubstituted oxindoles through Pd-catalyzed intramolecular cyanoamidation
}

\author{
AUTHOR(S): \\ Yasui, Yoshizumi; Kamisaki, Haruhi; Ishida, \\ Takayuki; Takemoto, Yoshiji
}

\section{CITATION:}

Yasui, Yoshizumi ...[et al]. Synthesis of 3,3-disubstituted oxindoles through Pd-catalyzed intramolecular cyanoamidation. Tetrahedron 2010, 66(11): 1980-1989

\section{ISSUE DATE:}

2010-03-13

URL:

http://hdl.handle.net/2433/101563

RIGHT:

c 2010 Elsevier Ltd. All rights reserved.; This is not the published version. Please cite only the published version.; この論文は出版社版でありませ ん。引用の際には出版社版をご確認ご利用ください。 
Synthesis of 3,3-Disubstituted Oxindoles through Pd-Catalyzed Intramolecular Cyanoamidation

Yoshizumi Yasui,a Haruhi Kamisaki, ${ }^{\mathrm{b}}$ Takayuki Ishida ${ }^{\mathrm{b}}$ and Yoshiji Takemotob*

a World Premier International Research Center, Advanced Institute for Materials Research, Tohoku University, Aoba, Sendai, 980-8578, Japan

b Graduate School of Pharmaceutical Sciences, Kyoto University, Yoshida, Sakyo-ku, Kyoto, 606-8501, Japan, Tel.: +81-75-753-4528; fax: +81-75-753-4569; e-mail: takemoto@pharm.kyoto-u.ac.jp.

Abstract. The cyanoamidation of olefins was achieved. When $N$-(2-vinylphenyl)cyanoformamides were treated with palladium catalyst, intramolecular cyanoamidation took place to give corresponding 3,3-disubstituted oxindoles. $\mathrm{P}(t-\mathrm{Bu})_{3}$ showed a remarkable effect on this reaction. When it was used with $\operatorname{Pd}(\mathrm{dba})_{2}$, the reaction was completed in $15 \mathrm{~min}$ at $100{ }^{\circ} \mathrm{C}$ for many substrates. Furthermore, the enantioselective cyanoamidation was accomplished with $\mathrm{Pd}(\mathrm{dba})_{2}$ and an optically active phosphoramidite to provide optically active 3,3-disubstituted oxindoles. Manipulation of the resulting oxindoles has been studied.

\section{Introduction}

Compounds possessing the 3,3-disubstituted oxindole substructure have received considerable pharmacological attention, and have frequently been used as synthetic intermediates for indole alkaloid synthesis. ${ }^{1}$ To obtain optically active 3,3-disubstituted oxindoles, various classes of enantioselective methodologies have been applied. These can be classified on the basis of retrosynthetic disconnection (Figure 1). Formation of the bond between $\mathrm{C}(3)$ and the benzene ring (path a), represents an enantioselective Heck reaction pioneered by Overman et al. ${ }^{2}$ Recently, this strategy has been expanded to an arylpalladation-cyanation cascade. ${ }^{3}$ Alternatively, the same bond was constructed through palladium-catalyzed enantioselective intramolecular $\alpha$-arylation of acetanilide derivatives. ${ }^{4}$ The strategies starting from 3-monosubstituted oxindole (path b) have also been extensively studied; namely, optically active pyridine-catalyzed acyl migrations, ${ }^{5}$ palladium- or molybdenum-catalyzed allylations, ${ }^{6}$ palladium-catalyzed trimethylenemethane $[3+2]$-cycloadditions, ${ }^{7}$ cinchona-alkaloid-catalyzed enantioselective aldol-type reactions, ${ }^{8}$ palladium-catalyzed enantioselective arylations and vinylations, ${ }^{9}$ organocatalytic Mannich reactions, ${ }^{10}$ and enantioselective Claisen rearrangements. ${ }^{11,12}$ In this project, we studied the synthesis of optically active 3,3-disubstituted oxindoles by bond formation between an amide carbonyl and C(3) (path c), which has not been explored previously. 


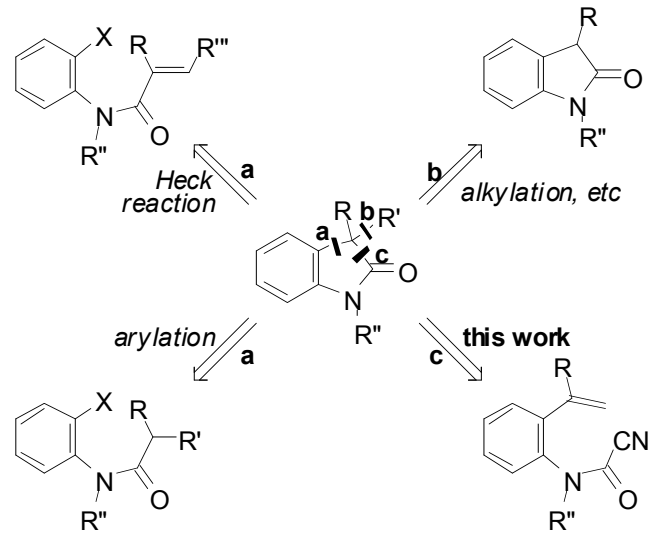

Figure 1. Enantioselective synthesis of 3,3-disubstituted oxindoles.

Recently, we have been interested in developing lactam formation through intramolecular insertion of carbamoyl transition metal complexes (Figure 2). ${ }^{13}$ The catalytic process starts with the oxidative addition of formamide derivatives to low valent transition metal species to generate carbamoyl complex $\mathbf{A}$. This complex undergoes ring closure via amidometalation. Either reductive elimination or $\beta$-hydride elimination leads to the final product. The advantages of our strategy are: i) providing access to highly functionalized and substituted lactams, ii) in a single step, iii) from readily available starting materials, and iv) under neutral conditions.

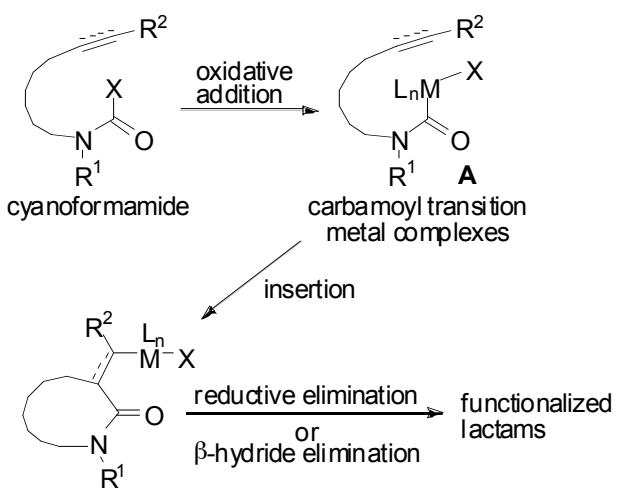

Figure 2. Synthesis of lactams through carbamoyl transition metal complexes.

In line with this reaction design, several lactam forming methods were developed (Figure 3). Alkylidene lactams were synthesized from alkynyl formamides through rhodium-catalyzed hydroamidation ${ }^{14}$ and palladium-catalyzed cyanoamidation. ${ }^{15}$ Replacement of the alkyne with an alkene led to the formation of $\alpha, \alpha$-disubstituted lactams: a palladium-catalyzed Heck-type reaction proceeded from alkenyl chloroformamides to give $\alpha$-vinyl lactams. ${ }^{16}$ As part of these studies, the reaction of alkenyl cyanoformamides with palladium catalyst was found to give $\alpha$-cyanomethyl lactams. This reaction was applied to the synthesis of 3,3-disubstituted oxindoles and other $\alpha, \alpha$-disubstituted lactams and was 
expanded to enantioselective transformation. Details of this intramolecular cyanoamidation of alkenes are described herein. ${ }^{17}$
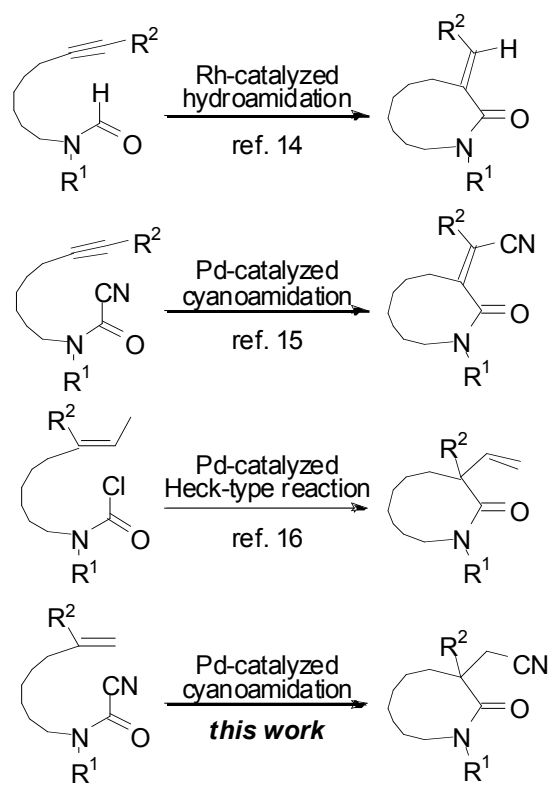

Figure 3. Transition-metal-catalyzed lactam formations studied in our group.

During the period when we were studying cyanoamidation, other carbocyanation reactions were developed extensively. ${ }^{18}$ Nishihara's group and Hiyama's group reported cyanoesterification of norbornenes and allenes. ${ }^{19,20}$ Hiyama also achieved a series of carbocyanation reactions through C-CN bond activation of aryl, ${ }^{21}$ alkynyl, $^{22}$ allyl, ${ }^{23}$ and alkyl $^{21 b}$ cyanides. Recently, intramolecular enantioselective arylcyanation has been achieved. ${ }^{24}$

\section{Results and Discussion}

\subsection{Pd-Catalyzed Intramolecular Cyanoamidation of Olefins}

Cyanoformamide $\mathbf{1 a}^{25}$ derived from commercially available 2-isopropenylaniline was treated with palladium catalyst in xylene at $130{ }^{\circ} \mathrm{C}$ (Table 1). Treatment of $10 \mathrm{~mol} \% \mathrm{Pd}\left(\mathrm{PPh}_{3}\right)_{4}$, under similar reaction conditions to these investigated for the intramolecular cyanoamidation of alkynes, ${ }^{15}$ gave the desired 3-cyanomethyl-3-methyloxindole $\mathbf{2 a}$ in quantitative yield after $15 \mathrm{~min}$ (entry 1). When the catalyst loading was reduced to $2 \mathrm{~mol} \%$, the reaction took $6 \mathrm{~h}$ to reach completion (entry 2). Interest in the reactivity profile of the ligand prompted us to test a variety of phosphine and phosphorus ligands in combination with $2 \mathrm{~mol} \% \mathrm{Pd}(\mathrm{dba})_{2}$. As a result, it was found that the catalyst generated from $\mathrm{P}(t-\mathrm{Bu})_{3}$ was extremely reactive. The cyanoformamide 1a was converted to oxindole $\mathbf{2 a}$ in $98 \%$ yield after 15 min even at $100{ }^{\circ} \mathrm{C}$ (entry 4). Further decrease of the temperature to $80{ }^{\circ} \mathrm{C}$ led to incomplete conversion (entry 5). In contrast to those relatively strongly donating monophosphorus ligands such as $\mathrm{PPh}_{3}$ and $\mathrm{P}(t-\mathrm{Bu})_{3}$, 
the conditions using weaker donating ligands (entries 6-8) and bisphosphorus ligands (entries 9-12) resulted in poor conversion.

Table 1. Pd-Catalyzed intramolecular cyanoamidation of olefins.

\begin{tabular}{|c|c|c|c|}
\hline entry & $\begin{array}{l}\text { catalyst } \\
(\mathrm{mol} \%)\end{array}$ & $\begin{array}{l}\text { time } \\
\text { (h) }\end{array}$ & $\begin{array}{l}\text { yield } \\
(\%)^{\mathrm{a}}\end{array}$ \\
\hline 1 & $\mathrm{Pd}\left(\mathrm{PPh}_{3}\right)_{4}(10)$ & 0.25 & 98 \\
\hline 2 & $\mathrm{Pd}\left(\mathrm{PPh}_{3}\right)_{4}(2)$ & 6 & quant \\
\hline 3 & $\mathrm{Pd}(\mathrm{dba})_{2}(2), \mathrm{PPh}_{3}(4)$ & 2 & 97 \\
\hline $4^{\mathrm{b}}$ & $\mathrm{Pd}(\mathrm{dba})_{2}(2), \mathrm{P}(t-\mathrm{Bu})_{3}(4)^{\mathrm{c}}$ & 0.25 & 98 \\
\hline $5^{\mathrm{d}}$ & $\mathrm{Pd}(\mathrm{dba})_{2}(2), \mathrm{P}(t-\mathrm{Bu})_{3}(4)^{\mathrm{c}}$ & 69 & $74(16)$ \\
\hline 6 & $\operatorname{Pd}(\mathrm{dba})_{2}(2), \mathrm{P}(2 \text {-furyl })_{3}(4)$ & 24 & $66(33)$ \\
\hline 7 & $\mathrm{Pd}(\mathrm{dba})_{2}(2), \mathrm{P}(\mathrm{OPh})_{3}(4)$ & 24 & $58(42)$ \\
\hline 8 & $\begin{array}{l}\mathrm{Pd}(\mathrm{dba})_{2}(2) \\
(t-\mathrm{BuO})_{2} \mathrm{PN}(i-\mathrm{Pr})_{2}(4)\end{array}$ & 24 & $16(63)$ \\
\hline 9 & $\operatorname{Pd}(\mathrm{dba})_{2}(2), \operatorname{BINAP}(2)$ & 24 & $6(91)$ \\
\hline 10 & $\operatorname{Pd}(\mathrm{dba})_{2}(2), \mathrm{dppb}(4)$ & 24 & $44(45)$ \\
\hline 11 & $\operatorname{Pd}(\mathrm{dba})_{2}(2), \mathrm{dppp}(4)$ & 24 & $11(78)$ \\
\hline 12 & $\operatorname{Pd}(\mathrm{dba})_{2}(2), \mathrm{dppf}(4)$ & 24 & $78(21)$ \\
\hline
\end{tabular}

${ }^{\mathrm{a}}$ The values in parentheses show the yield of recovered starting materials.

${ }^{\mathrm{b}}$ Reaction was performed at $100{ }^{\circ} \mathrm{C}$.

${ }^{\mathrm{c}} \mathrm{P}(t-\mathrm{Bu})_{3}$ was generated from $\mathrm{HBF}_{4} \cdot \mathrm{P}(t-\mathrm{Bu})_{3}$ and $\mathrm{Et}_{3} \mathrm{~N}$ in situ. ${ }^{26}$

${ }^{\mathrm{d}}$ Reaction was performed at $80^{\circ} \mathrm{C}$.

A variety of oxindoles were synthesized using $2 \mathrm{~mol} \% \mathrm{Pd}(\mathrm{dba})_{2}$ and $4 \mathrm{~mol} \% \mathrm{P}(t-\mathrm{Bu})_{3}$ at $100{ }^{\circ} \mathrm{C}(\mathrm{Table}$ 2). Most of the cyanoformamides were converted to the corresponding oxindoles in $15 \mathrm{~min}$. The substituent $\mathrm{R}^{2}$ on the vinyl group did not affect the reaction significantly, so a variety of oxindoles possessing different types of side chains has been made available (entries 1-7). An exception was the reaction of cyanoformamide 1e that required higher temperature and longer reaction time (entries 4 and 5). In particular, among the products, oxindoles $2 \mathbf{e}$ and $\mathbf{2 f}$ with two distinct functionalized side chains, namely cyanomethyl and silyloxyalkyl, possess high utility as synthetic intermediates for natural and synthetic targets. Indeed, a compound related to oxindole $\mathbf{2 f}$ was used as a key intermediate for synthetic studies on vincorine by our group. ${ }^{27}$ This reaction also tolerated substitution on the aromatic ring, which is considered to be crucial for medicinal studies (entries 8-10). 
Table 2. Synthesis of 3,3-disubstituted oxindoles.

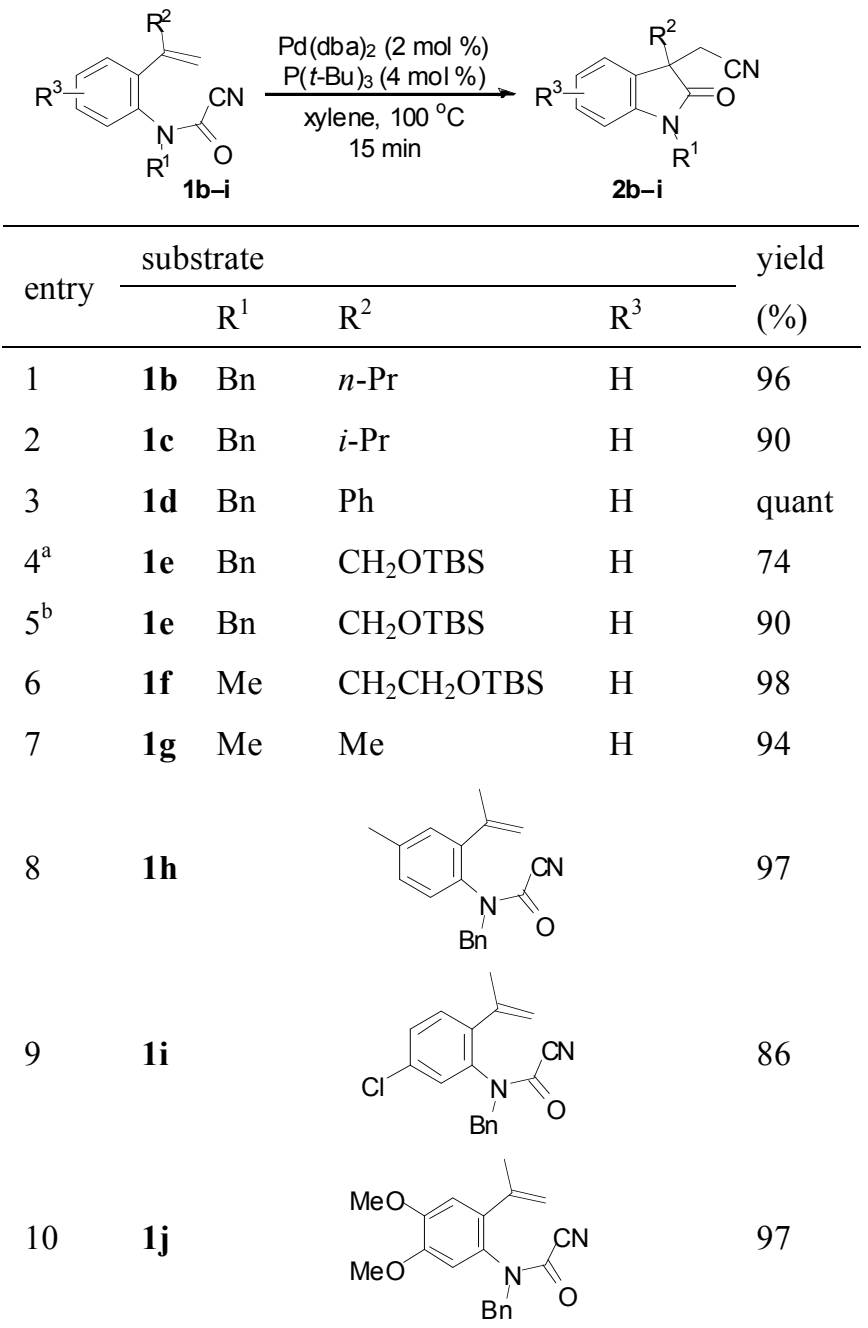

${ }^{\mathrm{a}}$ The reaction was allowed to run for $60 \mathrm{~h}$ and $12 \%$ of $1 \mathrm{e}$ was recovered.

${ }^{\mathrm{b}}$ The reaction was performed at $130{ }^{\circ} \mathrm{C}$ for $6 \mathrm{~h}$.

At present, the substituent on the amide nitrogen is limited to alkyl groups due to the low stability of the corresponding primary cyanoformamides and difficulty in the synthesis of other derivatives. However, it is worth noting that a methyl group on oxindole nitrogen is known to be cleaved under oxidative conditions. ${ }^{28}$ Thus, oxindoles not substituted on the amide nitrogen are available through cyanoamidation of $N$-methyl cyanoformamides followed by sequential demethylation (Scheme 1). ${ }^{29}$ 


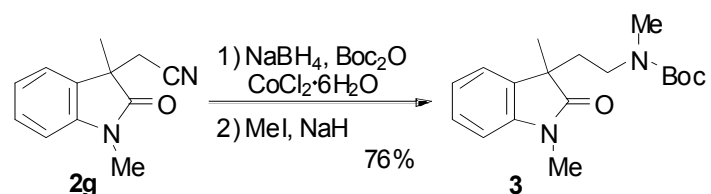

$2 \mathrm{Me}$

$3 \mathrm{Me}$

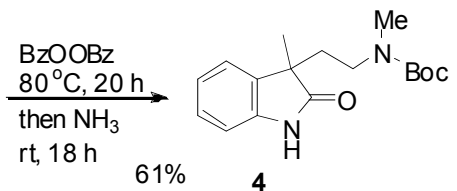

Scheme 1. Oxidative demethylation of the cyclized product. $^{29}$

This intramolecular cyanoamidation was not limited to oxindole formation (Table 3). When pyridine derivative 5 was treated with $10 \mathrm{~mol} \% \mathrm{Pd}\left(\mathrm{PPh}_{3}\right)_{4}$ (conditions A), azaoxindole 6 was isolated in 97\% yield after $1 \mathrm{~h}$ (entry 1 ). Conditions $\mathrm{B}$ using $\mathrm{P}(t-\mathrm{Bu})_{3}$ unexpectedly did not enable this transformation; cyclized product 6 was obtained in only $7 \%$ yield even after $24 \mathrm{~h}$, and $71 \%$ of the starting material was recovered (entry 2). It is apparent that under both conditions cyanoformamide 5 reacted more slowly than 1a. This difference likely comes from the presence of the nitrogen attached closely to the reaction site. Although such nitrogen atoms are known to promote some transition-metal-catalyzed reactions by functioning as a directing group, ${ }^{30}$ negative effects showed up in the case of $\mathbf{5}$. All the substrates tested had a rigid aromatic framework that brings the two reaction sites close. Next, $N$-butenyl cyanoformamide 7 with a flexible framework was tested. As a result, 7 gave the corresponding cyanomethyl- $\gamma$-lactam 8 in $95 \%$ yield by treatment of $10 \mathrm{~mol} \% \mathrm{Pd}\left(\mathrm{PPh}_{3}\right)_{4}$ (entry 3$)$. The catalyst generated with $\mathrm{P}(t \text { - } \mathrm{Bu})_{3}$ gave no product (entry 4). Furthermore, 6-membered lactam 10 and 7-membered lactam 12 were obtained from the reaction with 10 mol \% $\mathrm{Pd}\left(\mathrm{PPh}_{3}\right)_{4}$ (entries 5 and 7). Obviously, the $\mathrm{Pd}(\mathrm{dba})_{2}-\mathrm{P}(t-\mathrm{Bu})_{3}$ system (conditions B) was not effective for all the compounds in Table 3. We hypothesize that this system generates reactive but unstable catalytic species with short lifetimes, which are sensitive to neighboring heteroatoms (for 5) or are not sufficiently stable to promote the cyclization of the substrates that require large conformational changes (for 7, 9 and 11). Nevertheless, this intramolecular cyanoamidation strategy is not limited to 3,3-disubstituted oxindoles but is also effective for the synthesis of other $\alpha, \alpha$-disubstituted lactam. 
Table 3. Synthesis of $\alpha, \alpha$-disubstituted lactams through intramolecular cyanoamidation.

\begin{tabular}{|c|c|c|c|c|c|c|}
\hline entry & substrate & product & conditions $^{\mathrm{a}}$ & time $(\mathrm{h})$ & yield (\%) & $\begin{array}{l}\text { recovery of } \\
\text { SM (\%) }\end{array}$ \\
\hline 1 & & & A & 1 & 97 & - \\
\hline 2 & & 6 & B & 24 & 7 & 71 \\
\hline 3 & & & A & 0.25 & 95 & - \\
\hline 4 & $\mathrm{Bn}$ & & B & 24 & 0 & 89 \\
\hline 5 & & & A & 24 & 45 & 38 \\
\hline 6 & & 1 & B & 24 & 0 & 92 \\
\hline 7 & & & A & 10 & quant & - \\
\hline 8 & I & & B & 24 & 0 & 94 \\
\hline
\end{tabular}

${ }^{\mathrm{a}}$ Conditions $\mathrm{A}: \mathrm{Pd}\left(\mathrm{PPh}_{3}\right)_{4}(10 \mathrm{~mol} \%)$ at $130{ }^{\circ} \mathrm{C}$; Conditions B: $\mathrm{Pd}(\mathrm{dba})_{2}(2 \mathrm{~mol} \%), \mathrm{P}(t-\mathrm{Bu})_{3}(4 \mathrm{~mol} \%)$, at $100{ }^{\circ} \mathrm{C}$.

\subsection{Enantioselective Synthesis of 3,3-Disubstituted Oxindoles}

Next, we studied the enantioselective version of this intramolecular cyanoamidation (Table 4). We started the investigation with optically active monophosphorus ligands according to the results shown in Table 1. Initial attempts were made with well-known phosphine derivatives such as NMDPP (L1) ${ }^{31}$ and MOP $(\mathbf{L 2})^{32}$ with $2 \mathrm{~mol} \% \mathrm{Pd}(\mathrm{dba})_{2}$ in xylene at $130{ }^{\circ} \mathrm{C}$ (entries 1 and 2). As expected, these electron rich ligands promoted the reaction efficiently to give oxindole $\mathbf{2 a}$ in quantitative yields after 15 min, but only slight enantioselectivity was observed. Phosphonite $\mathbf{L 3}^{33}$ and phosphonic diamide $\mathbf{L} 4^{34}$ promoted the reaction poorly, and no enantioselectivity was detected (entries 3 and 4). However, the reaction with phosphoramidite $\mathbf{L 5}^{35}$ synthesized from BINOL and dimethylamine gave $(S)$-oxindole $\mathbf{2 a}$ in $80 \%$ isolated yield and $16 \%$ ee (entry 5). It was found that the size of the amino group significantly affected the enantioselectivity. The selectivity increased from $16 \%$ ee to $26 \%$ ee when dimethylamine was changed to morpholine (entry 6). ${ }^{36}$ Phosphoramidite $\mathbf{L} 7^{36}$ derived from bulkier diisopropylamine gave $46 \%$ ee, and 
finally phosphoramidite $\mathbf{L 8}{ }^{37}$ with the bis[(R)-1-phenylethyl]amino group resulted in $69 \%$ ee with $96 \%$ isolated yield (entries 7 and 8). Changing the configuration of BINOL from $R$ to $S$ gave (R)-2a as a major product with lower selectivity and yield (entry 10). Phosphoramidites $\mathbf{L 9},{ }^{37} \mathbf{L 1 1},{ }^{38} \mathbf{L 1 2},{ }^{39}$ and $\mathbf{L 1 3}{ }^{40}$ derived from dimethyl BINOL, biphenol, spirobiindane diol, and TADDOL, respectively, unexpectedly resulted in higher reactivity than $\mathbf{L 8}$ but poorer selectivity (entries 9, 11-13). Bisphosphorus ligands L14, $\mathbf{L 1 5}^{41}$ and $\mathbf{L 1 6}{ }^{42}$ gave poor conversion and selectivity (entries 14-16).

Table 4. Intramolecular enantioselective cyanoamidation of olefins.

\begin{tabular}{|c|c|c|c|c|}
\hline entry & $\begin{array}{l}\text { ligand } \\
(\mathrm{mol} \%)\end{array}$ & time (h) & $\begin{array}{l}\text { yield } \\
(\%)^{\mathrm{a}}\end{array}$ & ee $(\%)$ \\
\hline 1 & L1 (4) & 0.25 & 98 & $7(R)$ \\
\hline 2 & L2 (4) & 0.25 & quant & $9(R)$ \\
\hline 3 & $\mathbf{L 3}(4)$ & 24 & $26(70)$ & 0 \\
\hline 4 & L4 (4) & 24 & $4(87)$ & 0 \\
\hline 5 & $\mathbf{L 5}(4)$ & 24 & 80 & $16(S)$ \\
\hline 6 & L6 (4) & 8 & 97 & $26(S)$ \\
\hline 7 & L7 (4) & 24 & 65 & $46(S)$ \\
\hline 8 & $\mathbf{L 8}(8)$ & 6 & 96 & $69(S)$ \\
\hline 9 & L9 (8) & 0.25 & quant & $16(S)$ \\
\hline 10 & L10 (8) & 24 & 76 & $25(R)$ \\
\hline 11 & L11 (8) & 0.25 & 93 & $15(S)$ \\
\hline 12 & L12 (8) & 0.25 & 97 & $44(S)$ \\
\hline 13 & L13 (2) & 3 & 95 & $32(S)$ \\
\hline 14 & L14 (2) & 24 & $6(91)$ & 0 \\
\hline 15 & L15 (2) & 48 & $33(58)$ & $5(S)$ \\
\hline 16 & L16 (2) & 48 & $51(38)$ & $31(S)$ \\
\hline
\end{tabular}

${ }^{\mathrm{a}}$ The values in parentheses show the yield of recovered starting materials. 

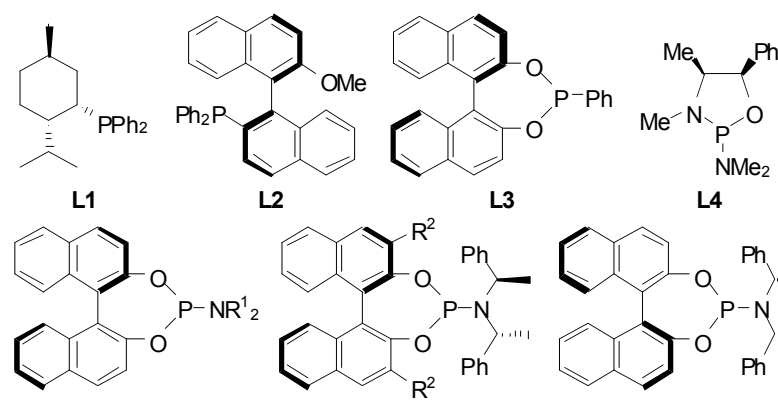

2

L3 L4

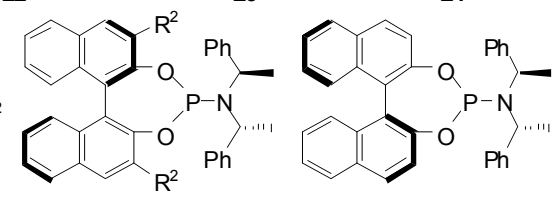

$\mathrm{L} 5\left(\mathrm{NR}_{2}^{1}=\mathrm{NMe}_{2}\right)$

L6 $\left(\mathrm{NR}_{2}{ }_{2}=-\mathrm{N} \_\right.$)

L8 $\left(R^{2}=H\right)$

L9 $\left(\mathrm{R}^{2}=\mathrm{Me}\right)$

L10

L7 $\left(\mathrm{NR}^{1}{ }_{2}=\mathrm{N}^{\mathrm{i}} \mathrm{Pr}_{2}\right)$

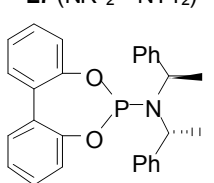

L11

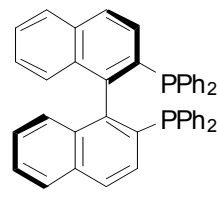

L14

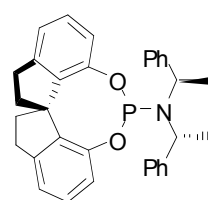

L12

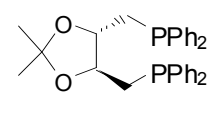

L15

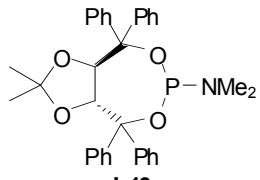

L13

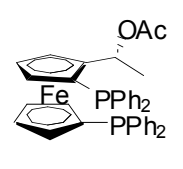

L16

The effects of solvents and additives were examined with using $2 \mathrm{~mol} \% \operatorname{Pd}(\mathrm{dba})_{2}$ and $8 \mathrm{~mol} \%$ phosphoramidite L8 (Table 5). When polar $N$-methyl-2-pyrrolidone (NMP) was used as the solvent, the reaction rate was markedly increased so that it reached completion in $15 \mathrm{~min}$, but the selectivity dropped to $56 \%$ ee (entry 2). The reaction in less-polar decalin gave better selectivity but poorer conversion (entry 3). To achieve good selectivity and conversion, a polar additive was employed in the reaction in decalin. Addition of $100 \mathrm{~mol} \%$ of NMP resulted in completion of the reaction in $2 \mathrm{~h}$ to give quantitative yield and $78 \%$ ee (entry 4). The amount of NMP was reduced to $8 \mathrm{~mol} \%$ and $2 \mathrm{~mol} \%$ but the effect remained comparable (entries 5 and 6). Next, the reaction temperature was reduced to $100{ }^{\circ} \mathrm{C}$ in the hope of enhancing the stereoselectivity. However, the reaction was not completed in $24 \mathrm{~h}$ even with 100 mol \% of NMP (entry 7). The more donating 1,3-dimethyl-2-imidazolidinone (DMI) was found to bring the reaction to completion (entry 8 ), and at the end, addition of $N, N$-dimethylpropylene urea (DMPU) gave quantitative yield and $81 \%$ ee (entry 9). It is worth noting that other Lewis bases such as 4-(N,N-dimethylamino)pyridine (DMAP) or hexamethylphosphorus triamide (HMPT) had no activation effect at all. Several possibilities for the effects of additive can be suggested: for example, i) accelerating formation of the reactive complex from $\mathrm{Pd}(\mathrm{dba})_{2}$ and phosphoramidite, and ii) stabilizing the coordinatively unsaturated species during the catalytic cycle. Additionally, we wish to propose other roles by noting the structural similarity of the effective additives and the reaction product: both have an amide or a urea functionality. After reductive elimination, the product must be cleaved from the palladium 
complex to induce the next catalytic cycle. However, the cyanomethyl oxindole should complex tightly to palladium, particularly in nonpolar solvents. Lewis base additives may promote this decomplexation. ${ }^{43}$

Table 5. Effect of solvent and additive.

\begin{tabular}{|c|c|c|c|c|c|c|c|}
\hline entry & solvent & additive ( $\mathrm{mol} \%$ ) & temp $\left({ }^{\circ} \mathrm{C}\right)$ & time (h) & yield (\%) & ee $(\%)^{a}$ & $\begin{array}{l}\text { recovery of SM } \\
(\%)\end{array}$ \\
\hline 1 & xylene & - & 130 & 6 & 96 & 69 & - \\
\hline 2 & NMP & - & 130 & 0.25 & 97 & 56 & - \\
\hline 3 & decalin & - & 130 & 24 & 83 & 74 & 10 \\
\hline 4 & decalin & NMP (100) & 130 & 2 & quant & 78 & - \\
\hline 5 & decalin & NMP (8) & 130 & 3 & 98 & 76 & - \\
\hline 6 & decalin & NMP (2) & 130 & 3 & 97 & 76 & - \\
\hline 7 & decalin & NMP (100) & 100 & 24 & 85 & 80 & 15 \\
\hline 8 & decalin & DMI (100) & 100 & 24 & 97 & 79 & - \\
\hline 9 & decalin & DMPU (100) & 100 & 24 & quant & 81 & - \\
\hline
\end{tabular}

${ }^{a}$ The major enantiomer was the $S$-isomer in all reactions.

Optically active 3,3-disubstituted oxindoles were synthesized under the conditions determined (Table 6). The substituent $\mathrm{R}^{2}$ on the vinyl group did not affect the reaction rate and yield in these enantioselective reactions but did affect their stereoselectivity (entries 1-5). An increase in bulkiness (Me $<n$ - $\operatorname{Pr}<$ $\mathrm{CH}_{2} \mathrm{OTBS}<i$ - $\mathrm{Pr} \approx \mathrm{Ph}$ ) resulted in a decrease in selectivity. $N$-Methyl cyanoformamide 1 g gave slightly lower selectivity than 1a (entry 6). Substitution on the aromatic ring did not affect enantioselectivity but unexpectedly changed the reactivity. An increased amount of catalyst was required to complete the reaction of $\mathbf{1} \mathbf{j}$ and $\mathbf{1} \mathbf{k}$ that have methoxy groups (entries 9,10 ). The reaction of cyanoformamide $\mathbf{1 1}$ with a substituent close to the vinyl group was not completed even with an increased amount of catalyst (entry 11). 
Table 6. Synthesis of optically active 3,3-disubstituted oxindoles.

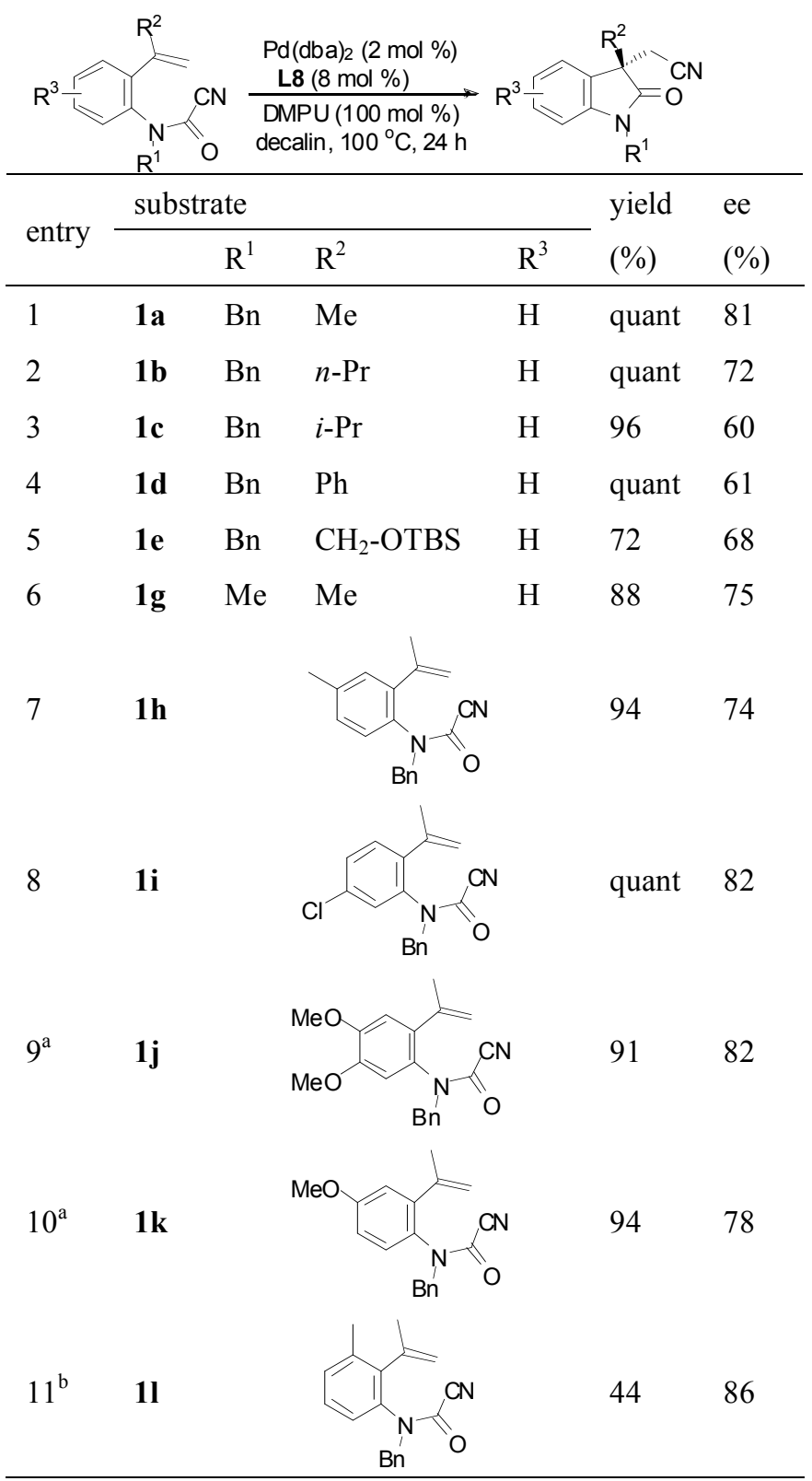

${ }^{\mathrm{a}} \mathrm{Pd}(\mathrm{dba})_{2}(5 \mathrm{~mol} \%)$ and $\mathbf{L 8}(20 \mathrm{~mol} \%)$ was used. ${ }^{\mathrm{b}} \mathrm{Pd}(\mathrm{dba})_{2}(5 \mathrm{~mol} \%)$ and $\mathbf{L 8}(10 \mathrm{~mol} \%)$ was used.

The conditions described were applied to the cyclization of aliphatic cyanoformamide 7 without modification (Scheme 2). Unfortunately, the starting material was not consumed completely after $24 \mathrm{~h}$ even at $130{ }^{\circ} \mathrm{C}$, and its selectivity was only $27 \%$ ee. Better conditions for enantioselective access to $\alpha, \alpha$-disubstituted lactams are being explored.

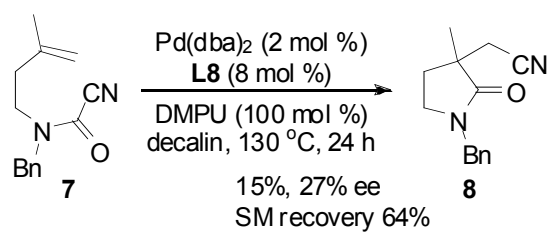


Scheme 2. Enantioselective cyclization of cyanoformamide 7.

\subsection{Mechanistic Considerations}

Although not much information is available on the reaction mechanism, we believe that the reaction proceeds through oxidative addition of the $\mathrm{CO}-\mathrm{CN}$ bond to palladium( $(0)$, followed by amidopalladation and reductive elimination (Figure 4). The alternative cyanopalladation pathway $(\mathbf{C} \rightarrow \mathbf{E})$, which may give the same final product, has been excluded by previous studies. ${ }^{15}$ We propose that the oxidative addition of the $\mathrm{CO}-\mathrm{CN}$ bond forms the four-coordinate intermediate $\mathbf{C}$ prior to insertion. Other pathways through the five-coordinate complex $\mathbf{F}$ or cationic complex $\mathbf{G}$ are unlikely, because the reaction is catalyzed effectively by large unidentate ligands and not by bidentate ligands. There are clear contrasts in terms of effective ligands between this reaction and other related enantioselective 3,3-disubstituted oxindole and indoline formations starting from allyl amine derivatives $\mathbf{H}$. These reactions proceed efficiently in the presence of optically active bidentate ligands. For example, the palladium-catalyzed enantioselective Heck reaction studied by Overman et al. gave the best result with BINAP, and the reaction pathway containing a five-coordinate complex and a cationic complex like $\mathbf{F}$ and $\mathbf{G}$ were proposed. ${ }^{2 b}$ More recently, enantioselective arylation-cyanation reactions ${ }^{3}$ and nickel catalyzed enantioselective intramolecular cyanoarylations ${ }^{24 a}$ have been reported to give the best result with optically active bidentate ligands.
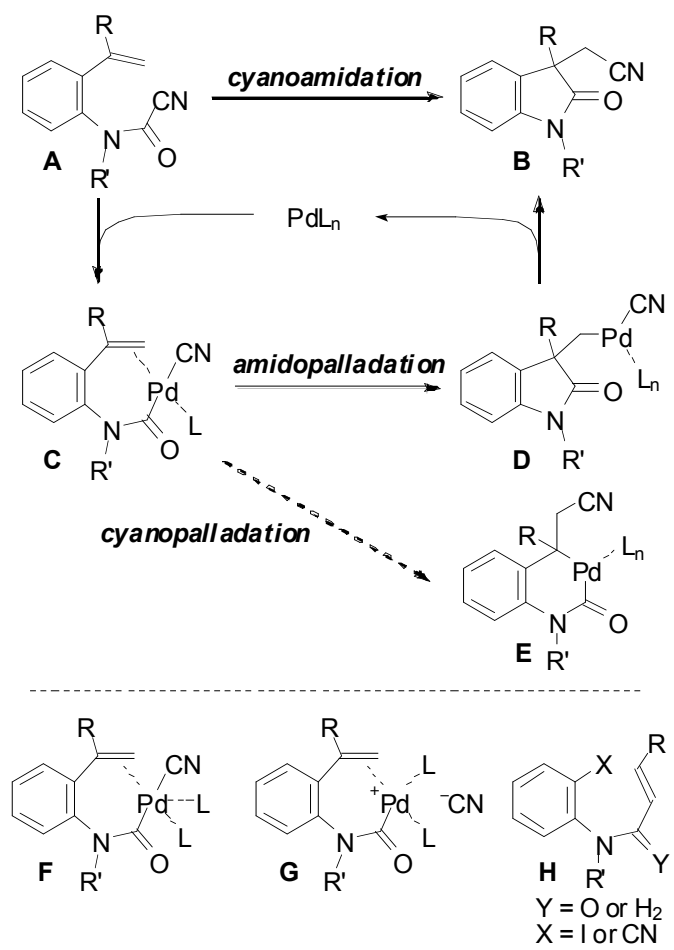

Figure 4. Plausible mechanism. 


\subsection{Synthetic Manipulations of 3,3-Disubstituted Oxindoles}

With the highly substituted oxindoles in hand, we studied synthetic manipulations of this class of compounds with the aim of providing drug-like structural motifs and realizing efficient access to natural products. Our approach illustrated in Figure 5 takes advantage of the presence of the cyano group incorporated by the cyanoamidation. Connection between the cyano group and substituent $\mathrm{R}^{2}$ on the quaternary carbon gives spirooxindole A. On the other hand, ring formation between the cyano group and the amide carbonyl provides fused indoline derivatives B with quaternary stereocenters at the ring junctions.

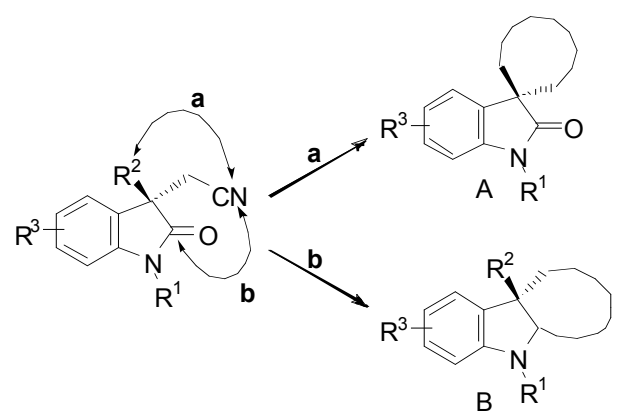

Figure 5. Strategy for the access to higher-ordered structures.

The first example is the synthesis of spirolactam $\mathbf{1 5}$ (Scheme 3). Starting from oxindole $\mathbf{2 f}$, removal of the TBS group followed by sequential oxidation and methylation gave cyanoester 14. This compound was cyclized through selective reduction of the cyano group by $\mathrm{CoCl}_{2} \cdot 6 \mathrm{H}_{2} \mathrm{O}$ and $\mathrm{NaBH}_{4}$, followed by treatment with $\mathrm{KOH}^{44}$ Two distinct amides $(N$-methyl and $N-\mathrm{H})$ in spirolactam 15 provide easy further manipulations.

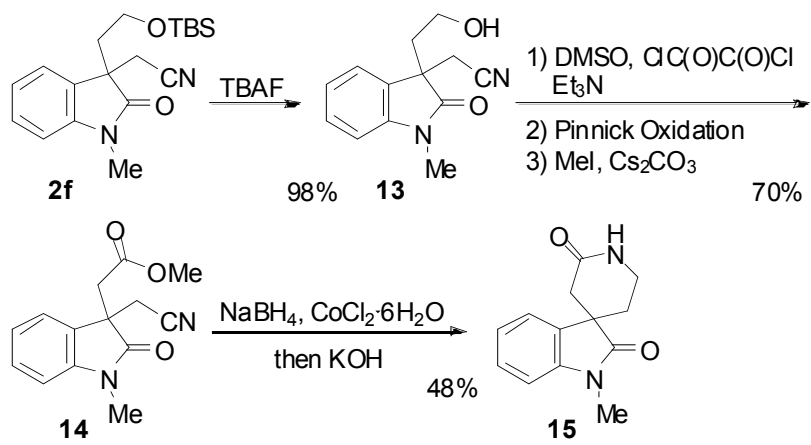

Scheme 3. Synthesis of spirolactam 15.

On the other hand, pyrroloindole 17 can also be formed in simple steps from oxindole 2a (Scheme 4). Again the selective reduction of the cyano group was achieved by $\mathrm{CoCl}_{2} \cdot 6 \mathrm{H}_{2} \mathrm{O}$ and $\mathrm{NaBH}_{4}$. Subsequent 
methoxycarbonylation gave carbonate 16. This compound was reductively cyclized to give pyrroloindole $\mathbf{1 7}{ }^{45}$ Comparison of the optical rotation of $\mathbf{1 7}$ with that reported in the literature showed that oxindole $\mathbf{2 a}$ has the $S$-configuration. ${ }^{46}$
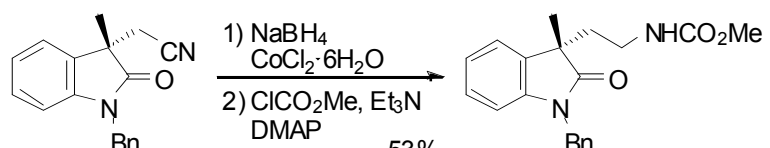

(S)-2a $(81 \%$ ee $)$

16

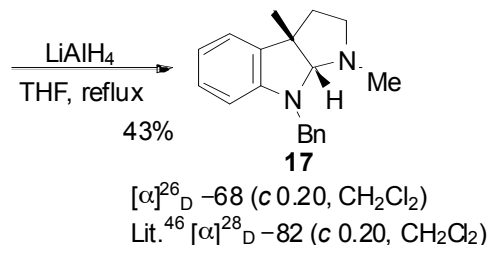

Scheme 4. Synthesis of pyrroloindole 17.

\section{Conclusions}

The palladium catalyzed intramolecular cyanoamidation of olefins was reported and shown to be an efficient strategy toward the synthesis of 3,3-disubstituted oxindoles as well as other $\alpha, \alpha$-disubstituted lactams. Electron rich phosphine ligands were found to promote this reaction smoothly. In particular, the catalyst generated from $\mathrm{Pd}(\mathrm{dba})_{2}$ and $\mathrm{P}(t-\mathrm{Bu})_{3}$ gave desired oxindoles in $15 \mathrm{~min}$ at $100{ }^{\circ} \mathrm{C}$. On the other hand, $\mathrm{Pd}\left(\mathrm{PPh}_{3}\right)_{4}$ provided better results for the synthesis of other $\alpha, \alpha$-disubstituted lactams. Efforts to expand this reaction to enantioselective conversions resulted in the finding that a catalytic amount of $\operatorname{Pd}(\mathrm{dba})_{2}$ and the phosphoramidite derived from $(R)$-BINOL and bis[(R)-1-phenylethyl]amine gave high yields and high enantioselectivity. The addition of DMPU was crucial to achieve the best results. This progress enables quick access to a variety of oxindoles and related compounds in a convenient manner.

\section{Experimental Section}

\subsection{General.}

Unless otherwise noted, all reactions were performed under argon. $\mathrm{Pd}\left(\mathrm{PPh}_{3}\right)_{4}$ was prepared by using the reported protocol. ${ }^{47} \mathrm{Pd}(\mathrm{dba})_{2}$ was purchased from Tokyo Chemical Industry Co., Ltd. $N, N$-Dimethyl propylene urea (DMPU) was distilled from $\mathrm{CaH}_{2}$. L8 and other optically active phosphoramidite ligands were prepared according to the literature procedure. 48 Silica gel column chromatography was performed with Kanto silica gel 60 (particle size, $63-210 \mu \mathrm{m}$ ). Proton nuclear magnetic resonance $\left({ }^{1} \mathrm{H}\right.$ NMR) spectra were recorded on a JEOL JNM-LA 500 at $500 \mathrm{MHz}$ or a JEOL JNM-AL 400 at $400 \mathrm{MHz}$. Chemical shifts are reported relative to $\mathrm{Me}_{4} \mathrm{Si}(\delta 0.00)$. Multiplicity is indicated by one or more of the following: s (singlet); d (doublet); t (triplet); q (quartet); 
$\mathrm{m}$ (multiplet); br (broad). Carbon nuclear magnetic resonance $\left({ }^{13} \mathrm{C} N \mathrm{NR}\right)$ spectra were recorded on a JEOL JNM-LA 500 at $126 \mathrm{MHz}$ or a JEOL JNM-AL 400 at $100 \mathrm{MHz}$. Chemical shifts are reported relative to $\mathrm{CDCl}_{3}(\delta 77.0)$. Infrared spectra were recorded on a FT/IR-4100 (JASCO) equipped with an attenuated total reflection (ATR) attachment or on a FT/IR-410 (JASCO) as a thin film on NaCl plate (thin film) or as a $\mathrm{KBr}$ pellet $(\mathrm{KBr})$ or as a $\mathrm{CHCl}_{3}$ solution $\left(\mathrm{CHCl}_{3}\right)$. Optical rotations were measured with a JASCO DIP-360 digital polarimeter. Enantiomer ratios were determined by chiral HPLC using a Shimadzu SPD-10A with Daicel Chemical Industries, LTD. Chiralpak AD-H $(0.46 \mathrm{~cm} \times 25 \mathrm{~cm})$, Chiralpak OJ-H $(0.46 \mathrm{~cm} \times 25 \mathrm{~cm})$, Chiralpak OD-H $(0.46 \mathrm{~cm} \mathrm{x} 25 \mathrm{~cm})$, or Chiralpak AS-H $(0.46 \mathrm{~cm} \times 25 \mathrm{~cm})$.

\subsection{Preparation of Cyanoformamides ${ }^{49}$}

4.2.1. Cyanoformamide 1a: To a solution of $N$-benzyl-2-(prop-1-en-2-yl)aniline $(3.20 \mathrm{~g}, 14.6 \mathrm{mmol})$ in $\mathrm{CH}_{2} \mathrm{Cl}_{2}(30 \mathrm{~mL})$ was added pyridine $(1.77 \mathrm{~mL}, 21.9 \mathrm{mmol})$ followed by triphosgene $(1.51 \mathrm{~g}, 5.10 \mathrm{mmol})$ at $-78{ }^{\circ} \mathrm{C}$. The reaction mixture was warmed to room temperature, diluted with $\mathrm{CHCl}_{3}$, and washed with 1 $\mathrm{M} \mathrm{HCl}$ and brine. The organic phase was dried over $\mathrm{MgSO}_{4}$, filtered, and concentrated under reduced pressure to give the crude chloroformamide. To a solution of this crude chloroformamide in MeCN (25 $\mathrm{mL}$ ) and $t$ - $\mathrm{BuOH}(5.0 \mathrm{~mL})$ were added 18-crown-6 (392 mg, $1.46 \mathrm{mmol})$ and $\mathrm{KCN}(1.43 \mathrm{~g}, 21.9 \mathrm{mmol})$, and the resulting mixture was stirred at $60^{\circ} \mathrm{C}$ for $2 \mathrm{~h}$. After removal of the solvents, water was added, and the mixture was extracted with $\mathrm{CHCl}_{3}$. The combined organic extracts were dried over $\mathrm{MgSO}_{4}$, filtered, and concentrated under reduced pressure. The residue obtained was purified by silica gel column chromatography (hexane/EtOAc $=95 / 5)$ to give oxindole $1 \mathbf{a}(3.83 \mathrm{~g}, 95 \%$ over 2 steps $)$ as a colorless oil: ${ }^{1} \mathrm{H}$ NMR $\left(500 \mathrm{MHz}, \mathrm{CDCl}_{3}, \delta\right) 7.40\left(\mathrm{dd}, 1 \mathrm{H}, J_{1}=J_{2}=7.6 \mathrm{~Hz}\right), 7.37\left(\mathrm{dd}, 1 \mathrm{H}, J_{1}=1.5, J_{2}=7.6 \mathrm{~Hz}\right)$, $7.31-7.25(\mathrm{~m}, 3 \mathrm{H}), 7.19\left(\mathrm{dd}, 1 \mathrm{H}, J_{1}=J_{2}=7.6 \mathrm{~Hz}\right), 7.15-7.13(\mathrm{~m}, 2 \mathrm{H}), 6.75(\mathrm{~d}, 1 \mathrm{H}, J=7.6 \mathrm{~Hz}), 6.66^{*}(\mathrm{~d}$, $J=7.7 \mathrm{~Hz}), 5.50(\mathrm{~d}, 1 \mathrm{H}, J=14.3 \mathrm{~Hz}), 5.35(\mathrm{~s}, 1 \mathrm{H}), 5.26^{*}(\mathrm{~s}), 5.08(\mathrm{~s}, 1 \mathrm{H}), 4.96^{*}(\mathrm{~s}), 4.09(\mathrm{~d}, 1 \mathrm{H}, J=$ $14.3 \mathrm{~Hz}), 2.12(\mathrm{~s}, 3 \mathrm{H}), 2.05^{*}(\mathrm{~s}) ;{ }^{13} \mathrm{C} \mathrm{NMR}\left(126 \mathrm{MHz}, \mathrm{CDCl}_{3}, \delta\right)$ 145.7, 142.4, 142.2, 135.1, 134.8, 130.7, $130.6,130.5,130.0 *, 129.5,129.3 * 129.1 *, 128.9,128.6,128.5,118.4,116.8^{*}, 111.0,52.4,23.7$; IR $\left(\mathrm{CHCl}_{3}\right) 2231,1677 \mathrm{~cm}^{-1}$; MS (EI) $m / z=276\left(\mathrm{M}^{+}\right)$; Anal. Calcd for $\mathrm{C}_{18} \mathrm{H}_{16} \mathrm{~N}_{2} \mathrm{O}: \mathrm{C}, 78.24 ; \mathrm{H}, 5.84 ; \mathrm{N}$, 10.14. Found: C, 78.35; H, 5.91; N, 10.02. (* Peaks of minor rotamer)

\subsection{General Procedure for Pd-Catalyzed Cyanoamidation}

4.3.1. Conditions using $10 \mathrm{~mol} \% \operatorname{Pd}\left(\mathrm{PPh}_{3}\right)_{4}$ (Table 1, entry 1): A solution of cyanoformamide 1a (100 $\mathrm{mg}, 0.362 \mathrm{mmol})$ and $\mathrm{Pd}\left(\mathrm{PPh}_{3}\right)_{4}(41.8 \mathrm{mg}, 0.0362 \mathrm{mmol})$ in xylene $(3.6 \mathrm{~mL})$ was stirred at $130{ }^{\circ} \mathrm{C}$ for 0.25 h. The mixture was subjected directly to silica gel column chromatography (hexane/EtOAc $=10 / 0 \rightarrow 8 / 2$ ) to give the oxindole $\mathbf{2 a}(98.2 \mathrm{mg}, 98 \%)$ as a colorless oil. ${ }^{1} \mathrm{H}$ NMR $\left(500 \mathrm{MHz}, \mathrm{CDCl}_{3}, \delta\right) 7.48(\mathrm{~d}, 1 \mathrm{H}, J=$ $7.6 \mathrm{~Hz}), 7.34-7.25(\mathrm{~m}, 5 \mathrm{H}), 7.23\left(\mathrm{dd}, 1 \mathrm{H}, J_{1}=J_{2}=7.6 \mathrm{~Hz}\right), 7.09\left(\mathrm{dd}, 1 \mathrm{H}, J_{1}=J_{2}=7.6 \mathrm{~Hz}\right), 6.78(\mathrm{~d}, 1 \mathrm{H}, J$ $=7.6 \mathrm{~Hz}), 4.95(\mathrm{~d}, 1 \mathrm{H}, J=16.5 \mathrm{~Hz}), 4.92(\mathrm{~d}, 1 \mathrm{H}, J=16.5 \mathrm{~Hz}), 2.91(\mathrm{~d}, 1 \mathrm{H}, J=16.8 \mathrm{~Hz}), 2.64(\mathrm{~d}, 1 \mathrm{H}, J=$ 
$16.8 \mathrm{~Hz}), 1.57$ (s, 3H); ${ }^{13} \mathrm{C} \mathrm{NMR}\left(126 \mathrm{MHz}, \mathrm{CDCl}_{3}\right.$, $\left.\delta\right)$ 177.9, 142.0, 135.5, 131.2, 129.3, 129.1, 128.0, 127.4, 123.5, 123.4, 116.8, 109.9, 45.1, 44.1, 26.4, 22.6; IR $\left(\mathrm{CHCl}_{3}\right) 1714 \mathrm{~cm}^{-1}$; MS (EI) $\mathrm{m} / z=276\left(\mathrm{M}^{+}\right)$; Anal. Calcd for $\mathrm{C}_{18} \mathrm{H}_{16} \mathrm{~N}_{2} \mathrm{O}$ : C, 78.24; H, 5.84; N, 10.14. Found: C, 78.18; H, 6.06; N, 10.12 .

4.3.2. Conditions using $2 \mathrm{~mol} \% \mathrm{Pd}(\mathrm{dba})_{2}$ and $4 \mathrm{~mol} \% \mathrm{P}\left(t-\mathrm{Bu}_{3}\right)$ (Table 1, entry 4): A solution of cyanoformamide $1 \mathrm{a}(100 \mathrm{mg}, 0.362 \mathrm{mmol}), \mathrm{Pd}(\mathrm{dba})_{2}(4.16 \mathrm{mg}, 0.00724 \mathrm{mmol}), \mathrm{P}\left(t-\mathrm{Bu}_{3}\right) \cdot \mathrm{HBF}_{4}(4.20 \mathrm{mg}$, $0.0145 \mathrm{mmol})$, and $\mathrm{Et}_{3} \mathrm{~N}(5.08 \mu \mathrm{L}, 0.0362 \mathrm{mmol})$ in xylene $(3.6 \mathrm{~mL})$ was stirred at $100{ }^{\circ} \mathrm{C}$ for $0.25 \mathrm{~h}$. The mixture was subjected directly to silica gel column chromatography (hexane/EtOAc $=10 / 0 \rightarrow 8 / 2$ ) to give the oxindole $2 \mathrm{a}(98.4 \mathrm{mg}, 98 \%)$.

4.3.3. Enantioselective cyanoamidation (Table 5, entry 9): A solution of cyanoformamide 1a (100 mg, $0.362 \mathrm{mmol}), \mathbf{L 8}(15.6 \mathrm{mg}, 0.0290 \mathrm{mmol}), \mathrm{DMPU}$ (0.043 mL, $0.36 \mathrm{mmol})$, and Pd(dba) 2 (4.2 mg, 0.0072 mmol) in decalin $(3.6 \mathrm{~mL})$ was stirred at $100{ }^{\circ} \mathrm{C}$ for $24 \mathrm{~h}$. The mixture was subjected directly to silica gel column chromatography (hexane/EtOAc $=10 / 0 \rightarrow 8 / 2)$ to give the oxindole 2a (99.4 mg, quant). HPLC [Chiralcel OD-H, hexane/2-propanol $=90 / 10,1.0 \mathrm{~mL} / \mathrm{min}, \lambda=210 \mathrm{~nm}$, retention times: (minor) $14.3 \mathrm{~min}$, (major) $17.5 \mathrm{~min}]$; $[\alpha]_{\mathrm{D}}^{26} 26.9$ (c=0.90 in $\mathrm{CHCl}_{3}, 81 \%$ ee).

4.3.4. Oxindole 2b: Colorless oil; ${ }^{1} \mathrm{H}$ NMR $\left(500 \mathrm{MHz}, \mathrm{CDCl}_{3}, \delta\right) 7.42\left(\mathrm{dd}, 1 \mathrm{H}, J_{1}=0.9 \mathrm{~Hz}, J_{2}=7.6 \mathrm{~Hz}\right)$, $7.33-7.25(\mathrm{~m}, 5 \mathrm{H}), 7.23\left(\mathrm{dd}, 1 \mathrm{H}, J_{1}=J_{2}=7.6 \mathrm{~Hz}\right), 7.10\left(\mathrm{ddd}, 1 \mathrm{H}, J_{1}=0.9 \mathrm{~Hz}, J_{2}=J_{3}=7.6 \mathrm{~Hz}\right), 6.78(\mathrm{~d}$, $1 \mathrm{H}, J=7.6 \mathrm{~Hz}), 4.96(\mathrm{~d}, 1 \mathrm{H}, J=15.6 \mathrm{~Hz}), 4.90(\mathrm{~d}, 1 \mathrm{H}, J=15.6 \mathrm{~Hz}), 2.87$ (d, 1H, J=16.8 Hz), 2.65 (d, $1 \mathrm{H}, J=16.8 \mathrm{~Hz}), 2.02\left(\mathrm{ddd}, 1 \mathrm{H}, J_{1}=5.2 \mathrm{~Hz}, J_{2}=10.7 \mathrm{~Hz}, J_{3}=13.1 \mathrm{~Hz}\right), 1.98\left(\mathrm{ddd}, 1 \mathrm{H}, J_{1}=5.2 \mathrm{~Hz}, J_{2}=\right.$ $\left.10.7 \mathrm{~Hz}, J_{3}=13.1 \mathrm{~Hz}\right), 1.08(\mathrm{~m}, 1 \mathrm{H}), 0.90(\mathrm{~m}, 1 \mathrm{H}), 0.82\left(\mathrm{dd}, 3 \mathrm{H}, J_{1}=J_{2}=7.3 \mathrm{~Hz}\right) ;{ }^{13} \mathrm{C} \mathrm{NMR}(126 \mathrm{MHz}$, $\left.\mathrm{CDCl}_{3}, \delta\right) 177.4,142.8,135.6,129.5,129.2,129.0,128.0,127.5,123.44,123.41,116.7,109.8,49.3,44.2$, 38.7, 26.3, 17.6, 14.0; IR (thin film) $1712 \mathrm{~cm}^{-1}$; MS (EI) $\mathrm{m} / \mathrm{z}=304\left(\mathrm{M}^{+}\right)$; HPLC [Chiralcel OD-H, hexane/2-propanol $=90 / 10,1.0 \mathrm{~mL} / \mathrm{min}, \lambda=210 \mathrm{~nm}$, retention times: (minor) $10.5 \mathrm{~min}$, (major) 13.1 $\min ] ;[\alpha]_{\mathrm{D}}^{26} 26.7$ ( $c=0.78$ in $\mathrm{CHCl}_{3}, 72 \%$ ee) .

4.3.5. Oxindole 2c: Colorless oil; ${ }^{1} \mathrm{H}$ NMR $\left(500 \mathrm{MHz}, \mathrm{CDCl}_{3}, \delta\right) 7.37\left(\mathrm{dd}, 1 \mathrm{H}, J_{1}=0.9, J_{2}=7.7 \mathrm{~Hz}\right)$, $7.33-7.25(\mathrm{~m}, 5 \mathrm{H}), 7.24\left(\mathrm{ddd}, 1 \mathrm{H}, J_{1}=1.2 \mathrm{~Hz}, J_{2}=J_{3}=7.7 \mathrm{~Hz}\right), 7.08\left(\mathrm{ddd}, 1 \mathrm{H}, J_{1}=0.9 \mathrm{~Hz}, J_{2}=J_{3}=7.7\right.$ $\mathrm{Hz}), 6.78(\mathrm{~d}, 1 \mathrm{H}, J=7.6 \mathrm{~Hz}), 4.98(\mathrm{~d}, 1 \mathrm{H}, J=15.5 \mathrm{~Hz}), 4.88(\mathrm{~d}, 1 \mathrm{H}, J=15.5 \mathrm{~Hz}), 2.98(\mathrm{~d}, 1 \mathrm{H}, J=16.4$ $\mathrm{Hz}), 2.74(\mathrm{~d}, 1 \mathrm{H}, J=16.4 \mathrm{~Hz}), 2.44-2.31(\mathrm{~m}, 1 \mathrm{H}), 0.97(\mathrm{~d}, 3 \mathrm{H}, J=7.1 \mathrm{~Hz}), 0.92(\mathrm{~d}, 3 \mathrm{H}, J=7.1 \mathrm{~Hz}) ;{ }^{13} \mathrm{C}$ NMR (126 MHz, $\mathrm{CDCl}_{3}$, $\left.\delta\right)$ 176.9, 143.0, 135.4, 129.0, 128.9, 128.8, 127.7, 127.3, 123.5, 122.9, 116.6, 109.4, 52.1, 43.9, 34.4, 23.9, 17.1, 16.8; IR (thin film) 2360, $1711 \mathrm{~cm}^{-1}$; MS (EI) m/z = $304\left(\mathrm{M}^{+}\right.$); Anal. Calcd for $\mathrm{C}_{20} \mathrm{H}_{20} \mathrm{~N}_{2} \mathrm{O}$ : C, 78.92; H, 6.62; N, 9.20. Found: C, 78.66; H, 6.52; N, 9.24.; HPLC [Chiralcel OD-H, hexane/2-propanol $=90 / 10,1.0 \mathrm{~mL} / \mathrm{min}, \lambda=210 \mathrm{~nm}$, retention times: (minor) $12.0 \mathrm{~min}$, (major) $16.0 \mathrm{~min}, 60 \%$ ee].

4.3.6. Oxindole 2d: Colorless oil; ${ }^{1} \mathrm{H}$ NMR $\left(500 \mathrm{MHz}, \mathrm{CDCl}_{3}, \delta\right) 7.41(\mathrm{~d}, 1 \mathrm{H}, J=7.7 \mathrm{~Hz}), 7.28-7.13(\mathrm{~m}$, $11 \mathrm{H}), 7.07\left(\mathrm{ddd}, 1 \mathrm{H}, J_{1}=1.0, J_{2}=J_{3}=7.7 \mathrm{~Hz}\right), 6.75(\mathrm{~d}, 1 \mathrm{H}, J=7.7 \mathrm{~Hz}), 4.82(\mathrm{~d}, 1 \mathrm{H}, J=15.9 \mathrm{~Hz}), 4.86$ $(\mathrm{d}, 1 \mathrm{H}, J=15.9 \mathrm{~Hz}), 3.33(\mathrm{~d}, 1 \mathrm{H}, J=16.5 \mathrm{~Hz}), 3.05(\mathrm{~d}, 1 \mathrm{H}, J=16.5 \mathrm{~Hz}) ;{ }^{13} \mathrm{C} \mathrm{NMR}\left(126 \mathrm{MHz}, \mathrm{CDCl}_{3}, \delta\right)$ $176.0,142.7$, 136.7, 135.1, 129.6, 129.0, 128.9, 128.4, 127.8, 127.1, 126.7, 125.2, 123.4, 116.4, 110.1, 
52.7, 44.1, 26.1; IR (ATR) 2353, $1716 \mathrm{~cm}^{-1}$; MS (EI) m/z = $338\left(\mathrm{M}^{+}\right)$; Anal. Calcd for $\mathrm{C}_{23} \mathrm{H}_{18} \mathrm{~N}_{2} \mathrm{O}: \mathrm{C}_{\text {, }}$ 81.63; H, 5.36; N, 8.28. Found: C, 81.43; H, 5.49; N, 8.01.; HPLC [Chiralcel OD-H, hexane/2-propanol = 70/30, $1.0 \mathrm{~mL} / \mathrm{min}, \lambda=210 \mathrm{~nm}$, retention times: (minor) $9.3 \mathrm{~min}$, (major) $13.4 \mathrm{~min}, 61 \%$ ee].

4.3.7. Oxindole 2e: Colorless oil; ${ }^{1} \mathrm{H}$ NMR $\left(400 \mathrm{MHz}, \mathrm{CDCl}_{3}, \delta\right) 7.53(\mathrm{~d}, 1 \mathrm{H}, J=7.7 \mathrm{~Hz}), 7.38-7.32$ (m, $5 \mathrm{H}), 7.28\left(\mathrm{dd}, 1 \mathrm{H}, J_{1}=J_{2}=7.7 \mathrm{~Hz}\right), 7.14\left(\mathrm{dd}, 1 \mathrm{H}, J_{1}=J_{2}=7.7 \mathrm{~Hz}\right), 6.81(\mathrm{~d}, 1 \mathrm{H}, J=7.7 \mathrm{~Hz}), 5.02(\mathrm{~d}, 1 \mathrm{H}$, $J=16.7 \mathrm{~Hz}), 4.98(\mathrm{~d}, 1 \mathrm{H}, J=16.7 \mathrm{~Hz}), 4.07$ (d, 1H, $J=9.5 \mathrm{~Hz}), 3.93(\mathrm{~d}, 1 \mathrm{H}, J=9.5 \mathrm{~Hz}), 3.10(\mathrm{~d}, 1 \mathrm{H}, J=$ $16.5 \mathrm{~Hz}), 2.86(\mathrm{~d}, 1 \mathrm{H}, J=16.5 \mathrm{~Hz}), 0.87(\mathrm{~s}, 9 \mathrm{H}), 0.06(\mathrm{~s}, 3 \mathrm{H}), 0.00(\mathrm{~s}, 3 \mathrm{H}) ;{ }^{13} \mathrm{C} \mathrm{NMR}\left(100 \mathrm{MHz}, \mathrm{CDCl}_{3}\right.$, б) $175.7,143.1,135.4,129.4,129.0,128.5,127.9,127.3,124.3,123.1,116.6,109.7,66.8,51.2,44.1$, 25.7, 21.8, 18.2, -5.5, -5.7; IR (thin film) 2353, $1716 \mathrm{~cm}^{-1}$; MS (EI) m/z = $406\left(\mathrm{M}^{+}\right)$; Anal. Calcd for $\mathrm{C}_{24} \mathrm{H}_{30} \mathrm{~N}_{2} \mathrm{O}_{2} \mathrm{Si}: \mathrm{C}, 70.90 ; \mathrm{H}, 7.44 ; \mathrm{N}, 6.89$. Found: C, 70.61; H, 7.46; N, 6.78.; HPLC [Chiralcel OD-H, hexane/2-propanol $=90 / 10,1.0 \mathrm{~mL} / \mathrm{min}, \lambda=210 \mathrm{~nm}$, retention times: (minor) $6.7 \mathrm{~min}$, (major) $8.2 \mathrm{~min}]$; $[\alpha]^{26}-5.2\left(\mathrm{c}=0.83\right.$ in $\mathrm{CHCl}_{3}, 68 \%$ ee $)$.

4.3.8. Oxindole 2f: Colorless oil; ${ }^{1} \mathrm{H}$ NMR $\left(400 \mathrm{MHz}, \mathrm{CDCl}_{3}, \delta\right) ; 7.43(\mathrm{~d}, 1 \mathrm{H}, J=7.8 \mathrm{~Hz}), 7.36(\mathrm{dd}, 1 \mathrm{H}$, $\left.J_{1}=J_{2}=7.8 \mathrm{~Hz}\right), 7.13\left(\mathrm{dd}, 1 \mathrm{H}, J_{1}=J_{2}=7.8 \mathrm{~Hz}\right), 6.89(\mathrm{~d}, 1 \mathrm{H}, J=7.8 \mathrm{~Hz}), 3.51-3.39(\mathrm{~m}, 2 \mathrm{H}), 3.22(\mathrm{~s}$, $3 \mathrm{H}), 2.92(\mathrm{~d}, 1 \mathrm{H}, J=16.6 \mathrm{~Hz}), 2.58(\mathrm{~d}, 1 \mathrm{H}, J=16.6 \mathrm{~Hz}), 2.32-2.25$ (m, 1H), 2.20-2.15 (m, 1H), 0.77 (s, 9H), -0.12 (s, 3H), -0.13 (s, 3H); $\left.{ }^{13} \mathrm{C} \mathrm{NMR} \mathrm{(100} \mathrm{MHz,} \mathrm{CDCl}_{3}, \delta\right)$ 177.1, 143.8, 129.4, 128.9, 123.9, 123.1, 116.9, 108.8, 59.2, 47.5, 37.9, 26.8, 26.6, 25.9, 18.3, -5.64; IR $\left(\mathrm{CHCl}_{3}\right) 2251,1719 \mathrm{~cm}^{-1}$; MS (FAB) $m / z=345\left(\mathrm{M}+\mathrm{H}^{+}\right)$; Anal. Calcd for $\mathrm{C}_{19} \mathrm{H}_{28} \mathrm{~N}_{2} \mathrm{O}_{2} \mathrm{Si}: \mathrm{C}, 66.24 ; \mathrm{H}, 8.19 ; \mathrm{N}, 8.13$. Found: C, 65.91; $\mathrm{H}$, $8.19 ; \mathrm{N}, 8.04$.

4.3.9. Oxindole 2g: Colorless oil; ${ }^{1} \mathrm{H}$ NMR $\left(500 \mathrm{MHz}, \mathrm{CDCl}_{3}, \delta\right) 7.48(\mathrm{~d}, 1 \mathrm{H}, J=8.0 \mathrm{~Hz}), 7.36(\mathrm{dd}, 1 \mathrm{H}$, $\left.J_{1}=J_{2}=8.0 \mathrm{~Hz}\right), 7.14\left(\mathrm{dd}, 1 \mathrm{H}, J_{1}=J_{2}=8.0 \mathrm{~Hz}\right), 6.92(\mathrm{~d}, 1 \mathrm{H}, J=8.0 \mathrm{~Hz}), 3.25(\mathrm{~s}, 3 \mathrm{H}), 2.85(\mathrm{~d}, 1 \mathrm{H}, J=$ $16.4 \mathrm{~Hz}), 2.58(\mathrm{~d}, 1 \mathrm{H}, J=16.4 \mathrm{~Hz}), 1.53(\mathrm{~s}, 3 \mathrm{H}) ;{ }^{13} \mathrm{C} \mathrm{NMR}\left(126 \mathrm{MHz}, \mathrm{CDCl}_{3}, \delta\right)$ 177.7, 142.9, 131.2, $129.3,123.4,123.3,116.8,108.8,44.9,26.6,26.3,22.2$; IR (thin film) $1715 \mathrm{~cm}^{-1}$; MS (EI) $m / z=200$ $\left(\mathrm{M}^{+}\right)$; Anal. Calcd for $\mathrm{C}_{12} \mathrm{H}_{12} \mathrm{~N}_{2} \mathrm{O}$ : C, 71.98; H, 6.04; N, 13.99. Found: C, 71.70; H, 6.08; N, 13.85.; HPLC [Chiralcel AD-H, hexane/2-propanol $=90 / 10,1.0 \mathrm{~mL} / \mathrm{min}, \lambda=210 \mathrm{~nm}$, retention times: (minor) $8.4 \mathrm{~min}$, (major) $9.6 \mathrm{~min}]$; $[\alpha]^{26} 63.6\left(c=0.93\right.$ in $\mathrm{CHCl}_{3}, 75 \%$ ee).

4.3.10. Oxindole 2h: Colorless oil; ${ }^{1} \mathrm{H}$ NMR (400 MHz, $\left.\mathrm{CDCl}_{3}, \delta\right) 7.32-7.23(\mathrm{~m}, 6 \mathrm{H}), 7.01(\mathrm{~d}, 1 \mathrm{H}, J=$ $7.8 \mathrm{~Hz}), 6.66(\mathrm{~d}, 1 \mathrm{H}, J=7.8 \mathrm{~Hz}), 4.91(\mathrm{~s}, 2 \mathrm{H}), 2.88(\mathrm{~d}, 1 \mathrm{H}, J=16.5 \mathrm{~Hz}), 2.63(\mathrm{~d}, 1 \mathrm{H}, J=16.5 \mathrm{~Hz}), 2.32$ (s, 3H), $1.56(\mathrm{~s}, 3 \mathrm{H}) ;{ }^{13} \mathrm{C} \mathrm{NMR}\left(100 \mathrm{MHz}, \mathrm{CDCl}_{3}, \delta\right)$ 177.8, 139.6, 135.6, 133.1, 131.2, 129.5, 129.0, 127.9, 127.3, 124.1, 116.8, 109.6, 45.0, 44.0, 26.3, 22.6, 21.1; IR (thin film) $1712 \mathrm{~cm}^{-1}$; MS (EI) $m / z=$ $290\left(\mathrm{M}^{+}\right)$; Anal. Calcd for $\mathrm{C}_{19} \mathrm{H}_{18} \mathrm{~N}_{2} \mathrm{O}$ : C, 78.59; H, 6.25; N, 9.65. Found: C, 78.55; H, 6.41; N, 9.53.; HPLC [Chiralcel OD-H, hexane/2-propanol $=90 / 10,1.0 \mathrm{~mL} / \mathrm{min}, \lambda=210 \mathrm{~nm}$, retention times: (minor) $11.4 \mathrm{~min}$, (major) $15.1 \mathrm{~min}]$; $[\alpha]^{26} 22.9\left(c=1.38\right.$ in $\mathrm{CHCl}_{3}, 74 \%$ ee).

4.3.11. Oxindole 2i: Colorless solid; mp. 96.5-97.2 ${ }^{\circ} \mathrm{C} ;{ }^{1} \mathrm{H} \mathrm{NMR}\left(400 \mathrm{MHz}, \mathrm{CDCl}_{3}, \delta\right) 7.39$ (d, $1 \mathrm{H}, \mathrm{J}=$ $7.8 \mathrm{~Hz}), 7.37-7.28(\mathrm{~m}, 5 \mathrm{H}), 7.08\left(\mathrm{dd}, 1 \mathrm{H}, J_{1}=1.7 \mathrm{~Hz}, J_{2}=7.8 \mathrm{~Hz}\right), 6.78(\mathrm{~d}, 1 \mathrm{H}, J=1.7 \mathrm{~Hz}), 4.90(\mathrm{~s}, 2 \mathrm{H})$, $2.89(\mathrm{~d}, 1 \mathrm{H}, J=16.6 \mathrm{~Hz}), 2.63(\mathrm{~d}, 1 \mathrm{H}, J=16.6 \mathrm{~Hz}), 1.57(\mathrm{~s}, 3 \mathrm{H}) ;{ }^{13} \mathrm{C} \mathrm{NMR}\left(100 \mathrm{MHz}, \mathrm{CDCl}_{3}, \delta\right) 177.9$, 
$143.3,135.3,135.0,129.5,129.3,128.3,127.4,124.4,123.5,116.5,110.6,44.9,44.2,26.4,22.6$; IR (KBr) $1680 \mathrm{~cm}^{-1}$; MS (EI) $m / z=310\left(\mathrm{M}^{+}\right)$; Anal. Calcd for $\mathrm{C}_{18} \mathrm{H}_{15} \mathrm{ClN}_{2} \mathrm{O}: \mathrm{C}, 69.57 ; \mathrm{H}, 4.86$; N, 9.01. Found: C, 69.58; H, 5.10; N, 9.14.; HPLC [Chiralcel OD-H, hexane/2-propanol = 90/10, $1.0 \mathrm{~mL} / \mathrm{min}, \lambda=$ $210 \mathrm{~nm}$, retention times: (minor) $16.7 \mathrm{~min}$, (major) $22.4 \mathrm{~min}]$; $[\alpha]_{\mathrm{D}}^{26} 12.2\left(c=0.17\right.$ in $\mathrm{CHCl}_{3}, 82 \%$ ee).

4.3.12. Oxindole 2j: Colorless oil; ${ }^{1} \mathrm{H}$ NMR (400 MHz, $\left.\mathrm{CDCl}_{3}, \delta\right) 7.35-7.27(\mathrm{~m}, 5 \mathrm{H}), 7.07$ (s, $\left.1 \mathrm{H}\right), 6.36$ (s, 1H), $4.92(\mathrm{~s}, 2 \mathrm{H}), 3.87$ (s, 3H), 3.74 (s, 3H), 2.89 (d, 1H, J=16.6 Hz), 2.61 (d, 1H, J = 16.6 Hz), 1.56 $(\mathrm{s}, 3 \mathrm{H}) ;{ }^{13} \mathrm{C} \mathrm{NMR}\left(100 \mathrm{MHz}, \mathrm{CDCl}_{3}, \delta\right) 178.3,150.4,146.0,135.7,129.18,129.17,128.1,127.4,121.9$, 117.0, 108.3, 96.1, 57.0, 56.4, 45.3, 44.2, 26.7, 22.7; IR (thin film) $1710 \mathrm{~cm}^{-1}$; MS (EI) $m / z=336\left(\mathrm{M}^{+}\right)$; Anal. Calcd for $\mathrm{C}_{20} \mathrm{H}_{20} \mathrm{~N}_{2} \mathrm{O}_{3}$ : C, 71.41; H, 5.99; N, 8.33. Found: C, 71.18; H, 6.03; N, 8.27.; HPLC [Chiralcel AS-H, hexane/2-propanol $=90 / 10,1.0 \mathrm{~mL} / \mathrm{min}, \lambda=210 \mathrm{~nm}$, retention times: (minor) $40.2 \mathrm{~min}$, (major) $47.3 \mathrm{~min}]$; $[\alpha]_{\mathrm{D}}^{26} 36.4$ ( $c=0.98$ in $\mathrm{CHCl}_{3}, 82 \%$ ee).

4.3.13. Oxindole 2k: Colorless oil; ${ }^{1} \mathrm{H}$ NMR (400 MHz, $\left.\mathrm{CDCl}_{3}, \delta\right) 7.33-7.26(\mathrm{~m}, 5 \mathrm{H}), 7.08(\mathrm{~d}, 1 \mathrm{H}, J=$ $2.5 \mathrm{~Hz}), 6.74\left(\mathrm{dd}, 1 \mathrm{H}, J_{1}=2.5 \mathrm{~Hz}, J_{2}=8.5 \mathrm{~Hz}\right), 6.67(\mathrm{~d}, 1 \mathrm{H}, J=8.5 \mathrm{~Hz}), 4.90(\mathrm{~s}, 2 \mathrm{H}), 3.77(\mathrm{~s}, 3 \mathrm{H}), 2.89$ $(\mathrm{d}, 1 \mathrm{H}, J=16.6 \mathrm{~Hz}), 2.65(\mathrm{~d}, 1 \mathrm{H}, J=16.6 \mathrm{~Hz}), 1.56(\mathrm{~s}, 3 \mathrm{H}) ;{ }^{13} \mathrm{C} \mathrm{NMR}\left(100 \mathrm{MHz}, \mathrm{CDCl}_{3}, \delta\right) 177.6,156.7$, 135.6, 135.3, 132.5, 129.1, 128.0, 127.4, 116.7, 113.7, 110.7, 110.4, 55.9, 45.4, 44.1, 26.4, 22.6; IR (thin film) $1712 \mathrm{~cm}^{-1}$; MS (EI) $\mathrm{m} / z=306\left(\mathrm{M}^{+}\right)$; HPLC [Chiralcel AD-H, hexane/2-propanol = 90/10, 1.0 $\mathrm{mL} / \mathrm{min}, \lambda=210 \mathrm{~nm}$, retention times: (minor) $16.7 \mathrm{~min}$, (major) $19.1 \mathrm{~min}]$; $[\alpha]^{26} 13.7\left(c=1.11\right.$ in $\mathrm{CHCl}_{3}$, $78 \%$ ee).

4.3.14. Oxindole 21: Colorless oil; ${ }^{1} \mathrm{H}$ NMR (400 $\left.\mathrm{MHz}, \mathrm{CDCl}_{3}, \delta\right) 7.24-7.17(\mathrm{~m}, 5 \mathrm{H}), 7.03\left(\mathrm{dd}, 1 \mathrm{H}, J_{1}=\right.$ $\left.J_{2}=7.8 \mathrm{~Hz}\right), 6.77(\mathrm{~d}, 1 \mathrm{H}, J=7.8 \mathrm{~Hz}), 6.54(\mathrm{~d}, 1 \mathrm{H}, J=7.8 \mathrm{~Hz}), 4.91(\mathrm{~d}, 1 \mathrm{H}, J=15.8 \mathrm{~Hz}), 4.84(\mathrm{~d}, 1 \mathrm{H}, J=$ $15.8 \mathrm{~Hz}), 2.98(\mathrm{~d}, 1 \mathrm{H}, J=16.8 \mathrm{~Hz}), 2.91(\mathrm{~d}, 1 \mathrm{H}, J=16.8 \mathrm{~Hz}), 2.34(\mathrm{~s}, 3 \mathrm{H}), 1.50(\mathrm{~s}, 3 \mathrm{H}) ;{ }^{13} \mathrm{C}$ NMR $(100$ $\mathrm{MHz}, \mathrm{CDCl}_{3}$, $\left.\delta\right)$ 178.0, 142.8, 135.5, 134.6, 129.1, 129.0, 127.9, 127.3, 125.9, 116.30, 116.29, 107.9, 46.8, 44.1, 24.7, 21.6, 18.4; IR (thin film) $1713 \mathrm{~cm}^{-1}$; MS (EI) $m / z=290\left(\mathrm{M}^{+}\right)$; Anal. Calcd for $\mathrm{C}_{19} \mathrm{H}_{18} \mathrm{~N}_{2} \mathrm{O}: \mathrm{C}_{\text {, }}$ 78.59; H, 6.25; N, 9.65. Found: C, 78.32; H, 6.39; N, 9.53.; HPLC [Chiralcel OD-H, hexane/2-propanol= 90/10, $1.0 \mathrm{~mL} / \mathrm{min}, \lambda=210 \mathrm{~nm}$, retention times: (minor) $15.1 \mathrm{~min}$, (major) $19.6 \mathrm{~min}]$; $[\alpha]^{26}{ }_{\mathrm{D}}-37.5(c=$ 0.88 in $\mathrm{CHCl}_{3}, 86 \%$ ee).

4.3.15. Lactam 6: Colorless oil; ${ }^{1} \mathrm{H} \mathrm{NMR}\left(400 \mathrm{MHz}, \mathrm{CDCl}_{3}, \delta\right) 8.25$ (dd, $\left.1 \mathrm{H}, J_{1}=1.7 \mathrm{~Hz}, J_{2}=5.3 \mathrm{~Hz}\right)$, $7.73\left(\mathrm{dd}, 1 \mathrm{H}, J_{1}=1.7 \mathrm{~Hz}, J_{2}=7.3 \mathrm{~Hz}\right), 7.44-7.42(\mathrm{~m}, 2 \mathrm{H}), 7.32-7.24(\mathrm{~m}, 3 \mathrm{H}), 7.02\left(\mathrm{dd}, 1 \mathrm{H}, J_{1}=5.3 \mathrm{~Hz}\right.$, $\left.J_{2}=7.3 \mathrm{~Hz}\right), 5.01(\mathrm{~s}, 2 \mathrm{H}), 2.89(\mathrm{~d}, 1 \mathrm{H}, J=16.6 \mathrm{~Hz}), 2.53(\mathrm{~d}, 1 \mathrm{H}, J=16.6 \mathrm{~Hz}), 1.55(\mathrm{~s}, 3 \mathrm{H}) ;{ }^{13} \mathrm{C} \mathrm{NMR}$ (100 MHz, $\left.\mathrm{CDCl}_{3}, \delta\right)$ 177.0, 155.6, 148.2, 136.2, 131.0, 128.6, 128.2, 127.7, 125.2, 118.8, 116.3, 44.3, 42.8, 25.6, 21.7; IR (ATR) $1722 \mathrm{~cm}^{-1}$; MS (EI) $m / z=277\left(\mathrm{M}^{+}\right)$; Anal. Calcd for $\mathrm{C}_{17} \mathrm{H}_{15} \mathrm{~N}_{3} \mathrm{O}: \mathrm{C}, 73.63$; $\mathrm{H}$, $5.45 ; \mathrm{N}, 15.15$. Found: C, 73.78; H, 5.67; N, 15.02 .

4.3.16. Lactam 8: Colorless oil; ${ }^{1} \mathrm{H}$ NMR (400 MHz, $\left.\mathrm{CDCl}_{3}, \delta\right) 7.35-7.27$ (m, 3H), 7.22-7.21 (m, 2H), $4.49(\mathrm{~d}, 1 \mathrm{H}, J=14.6 \mathrm{~Hz}), 4.43(\mathrm{~d}, 1 \mathrm{H}, J=14.6 \mathrm{~Hz}), 3.24-3.21(\mathrm{~m}, 2 \mathrm{H}), 2.61$ (d, 1H, J = 16.8 Hz), 2.57 (d, $1 \mathrm{H}, J=16.8 \mathrm{~Hz}), 2.12\left(\mathrm{ddd}, 1 \mathrm{H}, J_{1}=J_{2}=8.2 \mathrm{~Hz}, J_{3}=13.1 \mathrm{~Hz}\right), 1.96\left(\mathrm{ddd}, 1 \mathrm{H}, J_{1}=5.2 \mathrm{~Hz}, J_{2}=6.4 \mathrm{~Hz}\right.$, 
$\left.J_{3}=13.1 \mathrm{~Hz}\right), 1.29(\mathrm{~s}, 3 \mathrm{H}) ;{ }^{13} \mathrm{C} \mathrm{NMR}\left(100 \mathrm{MHz}, \mathrm{CDCl}_{3}, \delta\right) 175.3,135.8,128.7,127.9,127.6,117.3,46.7$, 42.7, 42.5, 30.7, 26.2, 22.1; IR (thin film) $1689 \mathrm{~cm}^{-1}$; MS (EI) $\mathrm{m} / z=228\left(\mathrm{M}^{+}\right)$; Anal. Calcd for $\mathrm{C}_{14} \mathrm{H}_{16} \mathrm{~N}_{2} \mathrm{O}: \mathrm{C}, 73.66 ; \mathrm{H}, 7.06 ; \mathrm{N}$, 12.27. Found: C, 73.47; H, 7.22; N, 11.99 .

4.3.17. Lactam 10: Colorless oil; ${ }^{1} \mathrm{H}$ NMR (400 MHz, $\left.\mathrm{CDCl}_{3}, \delta\right) 7.39-7.25$ (m, 8H), 7.09 (d, 1H, $J=7.6$ Hz), $4.86(\mathrm{~d}, 1 \mathrm{H}, J=14.6 \mathrm{~Hz}), 4.74$ (d, 1H, $J=14.6 \mathrm{~Hz}), 4.48$ (d, 1H, $J=16.3 \mathrm{~Hz}), 4.41$ (d, 1H, $J=16.3$ $\mathrm{Hz}), 3.28(\mathrm{~d}, 1 \mathrm{H}, J=16.4 \mathrm{~Hz}), 2.96(\mathrm{~d}, 1 \mathrm{H}, J=16.4 \mathrm{~Hz}), 1.57(\mathrm{~s}, 3 \mathrm{H}) ;{ }^{13} \mathrm{C} \mathrm{NMR}\left(100 \mathrm{MHz}, \mathrm{CDCl}_{3}, \delta\right)$ 170.6, 136.5, 136.2, 130.1, 128.9, 128.3, 127.9, 127.8, 127.5, 125.9, 124.9, 117.6, 50.8, 49.2, 44.6, 27.4, 26.2; IR (thin film) 2248, $1642 \mathrm{~cm}^{-1}$; MS (EI) $m / z=290\left(\mathrm{M}^{+}\right)$; Anal. Calcd for $\mathrm{C}_{19} \mathrm{H}_{18} \mathrm{~N}_{2} \mathrm{O}: \mathrm{C}, 78.59 ; \mathrm{H}$, 6.25; N, 9.65. Found: C, 78.72; H, 6.24; N, 9.63.

4.3.18. Lactam 12: Colorless oil; ${ }^{1} \mathrm{H}$ NMR $\left(400 \mathrm{MHz}, \mathrm{CDCl}_{3}, \delta\right) 7.57-6.88(\mathrm{~m}, 13 \mathrm{H}), 5.12(\mathrm{~d}, 1 \mathrm{H}, J=$ $15.8 \mathrm{~Hz}), 5.02(\mathrm{~d}, 1 \mathrm{H}, J=15.8 \mathrm{~Hz}), 3.41(\mathrm{~d}, 1 \mathrm{H}, J=16.1 \mathrm{~Hz}), 3.24(\mathrm{~d}, 1 \mathrm{H}, J=16.1 \mathrm{~Hz}), 2.45^{*}(\mathrm{~d}, J=$ $16.1 \mathrm{~Hz}), 2.34 *(\mathrm{~d}, J=16.1 \mathrm{~Hz}), 2.02 *(\mathrm{~s}), 1.27(\mathrm{~s}, 3 \mathrm{H}) ;{ }^{13} \mathrm{C} \mathrm{NMR}\left(100 \mathrm{MHz}, \mathrm{CDCl}_{3}, \delta\right) 171.4,170.2^{*}$, 140.1, 139.9*, 139.4, 138.7*, 137.4*, 137.3, 136.5, 136.4*, 135.6, 135.0*, 130.7, 130.3*, 130.2, 130.0, $129.5^{*}, 129.2^{*}, 129.1,129.0,128.9^{*}, 128.6,128.5^{*}, 127.2,126.8^{*}, 126.6,126.5^{*}, 126.2,126.0^{*}, 124.1$, $123.1 *, 122.5,119.1,117.0^{*}, 54.6^{*}, 54.2,49.0,48.2^{*}, 28.1,24.1 * 24.0 *, 20.3$; IR (thin film) 1648,2360 $\mathrm{cm}^{-1}$; MS (EI) $m / z=352\left(\mathrm{M}^{+}\right)$; Anal. Calcd for $\mathrm{C}_{24} \mathrm{H}_{20} \mathrm{~N}_{2} \mathrm{O}: \mathrm{C}, 81.79 ; \mathrm{H}, 5.72 ; \mathrm{N}, 7.95$. Found: C, 81.54; $\mathrm{H}, 5.63 ; \mathrm{N}, 7.83$. (* Peaks of minor atropisomer)

\subsection{Synthesis of Spirolactam 15}

4.4.1. Alcohol 13: To a solution of compound $2 \mathrm{f}(148 \mathrm{mg}, 430 \mu \mathrm{mol})$ in THF $(15 \mathrm{~mL})$ was added $1 \mathrm{M}$ TBAF solution in THF $(970 \mu \mathrm{L}, 970 \mu \mathrm{mol})$ at $0{ }^{\circ} \mathrm{C}$. After stirring at the same temperature for $30 \mathrm{~min}$, water was added, and the mixture was extracted with EtOAc. The combined extracts were washed with brine, dried over $\mathrm{MgSO}_{4}$, filtered, and concentrated under reduced pressure. The residue was purified by silica gel column chromatography $\left(\mathrm{CHCl}_{3} / \mathrm{MeOH}=9 / 1 \rightarrow 6 / 4\right)$ to give $\mathbf{1 3}(96.8 \mathrm{mg}, 98 \%)$ as a white solid; mp 85.5-85.9 ${ }^{\circ} \mathrm{C} ;{ }^{1} \mathrm{H}$ NMR $\left(400 \mathrm{MHz}, \mathrm{CDCl}_{3}\right.$, $)$ ); $7.46(\mathrm{~d}, 1 \mathrm{H}, J=7.3 \mathrm{~Hz}), 7.39\left(\mathrm{dd}, 1 \mathrm{H}, J_{1}=7.8 \mathrm{~Hz}, J_{2}=\right.$ $7.5 \mathrm{~Hz}), 7.16\left(\mathrm{dd}, 1 \mathrm{H}, J_{1}=7.6 \mathrm{~Hz}, J_{2}=7.5 \mathrm{~Hz}\right), 6.93(\mathrm{~d}, 1 \mathrm{H}, J=7.8 \mathrm{~Hz}), 3.68-3.61(\mathrm{~m}, 1 \mathrm{H}), 3.50-3.42$ (m, 1H), $3.25(\mathrm{~s}, 3 \mathrm{H}), 2.95(\mathrm{~d}, 1 \mathrm{H}, J=16.6 \mathrm{~Hz}), 2.62(\mathrm{~d}, 1 \mathrm{H}, J=16.6 \mathrm{~Hz}), 2.37-2.31(\mathrm{~m}, 1 \mathrm{H}), 2.24-2.18$ (m, 1H), 1.72 (br, 1H); ${ }^{13} \mathrm{C}$ NMR (100 MHz, $\left.\mathrm{CDCl}_{3}, \delta\right) ; 177.9,143.5,129.7,129.1,123.7,123.6,116.6$, 109.1, 59.0, 47.6, 38.1, 26.8, 26.1; IR $\left(\mathrm{CHCl}_{3}\right) 3347,2251,1707,1613 \mathrm{~cm}^{-1}$; MS (FAB) $\mathrm{m} / z=231$ $\left(\mathrm{M}+\mathrm{H}^{+}\right)$; Anal. Calcd for $\mathrm{C}_{13} \mathrm{H}_{14} \mathrm{~N}_{2} \mathrm{O}_{2}: \mathrm{C}, 67.81 ; \mathrm{H}, 6.13 ; \mathrm{N}, 12.17$. Found: $\mathrm{C}, 67.64 ; \mathrm{H}, 6.22 ; \mathrm{N}, 12.00$.

4.4.2. Ester 14: To a solution of oxalyl chloride $(177 \mathrm{mg}, 1.39 \mathrm{mmol})$ in $\mathrm{CH}_{2} \mathrm{Cl}_{2}(2 \mathrm{~mL})$ was added DMSO (191 mg, $2.44 \mathrm{mmol})$ in $\mathrm{CH}_{2} \mathrm{Cl}_{2}(2 \mathrm{~mL})$ at $-78^{\circ} \mathrm{C}$. After stirring for $10 \mathrm{~min}$, a solution of $\mathbf{1 3}$ (112 $\mathrm{mg}, 0.487 \mathrm{mmol})$ in $\mathrm{CH}_{2} \mathrm{Cl}_{2}(2 \mathrm{~mL})$ was added at the same temperature. After stirring for $15 \mathrm{~min}, \mathrm{Et}_{3} \mathrm{~N}$ $(680 \mu \mathrm{l}, 4.88 \mathrm{mmol})$ was added, and the reaction mixture was warmed to room temperature. After stirring for $30 \mathrm{~min}$, the reaction mixture was quenched with $1 \mathrm{M} \mathrm{HCl}$ and brine. The mixture was extracted with 
$\mathrm{CHCl}_{3}$. The combined organic extracts were washed with saturated aqueous $\mathrm{NaHCO}_{3}$ and brine, dried over $\mathrm{MgSO}_{4}$, filtered, and concentrated under reduced pressure. The residue was dissolved in $t$ - $\mathrm{BuOH}(6$ $\mathrm{mL}$ ) and 2-methyl-2-butene $(3 \mathrm{~mL})$. To this solution was added $\mathrm{NaClO}_{2}(385 \mathrm{mg}, 3.41 \mathrm{mmol})$ in $\mathrm{NaH}_{2} \mathrm{PO}_{4}$ buffer solution $(1 \mathrm{mM}$ in water, $3.5 \mathrm{~mL})$. After stirring for $30 \mathrm{~min}$, organic solvents were concentrated under reduced pressure. The obtained residue was diluted with water and then washed with hexane. The aqueous layer was acidified with $1 \mathrm{M} \mathrm{HCl}$ to $\mathrm{pH} 2$ and extracted with $\mathrm{CHCl}_{3}$. Combined organic extracts were washed with brine, dried over $\mathrm{MgSO}_{4}$, filtered, and concentrated under reduced pressure. To the residue was added $\mathrm{CH}_{3} \mathrm{CN}(1.5 \mathrm{~mL}), \mathrm{Cs}_{2} \mathrm{CO}_{3}(170 \mathrm{mg}, 0.522 \mathrm{mmol})$ and $\mathrm{MeI}(54.4 \mu \mathrm{L}$, $0.873 \mathrm{mmol}$ ) at room temperature. After stirring for $11 \mathrm{~h}$, the reaction mixture was diluted with $\mathrm{CHCl}_{3}$ and filtered through a Celite pad. The filtrate was concentrated under reduced pressure, and the residue was purified by silica gel column chromatography (hexane/EtOAc $=9 / 1 \rightarrow 6 / 4)$ to give $14(87.9 \mathrm{mg}, 70 \%$ over 3 steps) as a colorless oil: ${ }^{1} \mathrm{H}$ NMR $\left(400 \mathrm{MHz}, \mathrm{CDCl}_{3}, \delta\right) ; 7.44(\mathrm{~d}, 1 \mathrm{H}, J=7.6 \mathrm{~Hz}), 7.38\left(\mathrm{dd}, 1 \mathrm{H}, J_{1}\right.$ $\left.=J_{2}=7.8 \mathrm{~Hz}\right), 7.12\left(\mathrm{dd}, 1 \mathrm{H}, J_{1}=7.6 \mathrm{~Hz}, J_{2}=7.5 \mathrm{~Hz}\right), 6.93(\mathrm{~d}, 1 \mathrm{H}, J=7.8 \mathrm{~Hz}), 3.53(\mathrm{~s}, 3 \mathrm{H}), 3.28(\mathrm{~s}, 3 \mathrm{H})$, 3.13-2.96 (m, 3H), $2.62(\mathrm{~d}, 1 \mathrm{H}, J=16.6 \mathrm{~Hz}) ;{ }^{13} \mathrm{C} \mathrm{NMR}\left(100 \mathrm{MHz}, \mathrm{CDCl}_{3}, \delta\right) ; 176.4,169.5,143.9,129.9$,

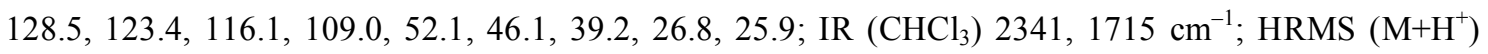
Calcd for $\mathrm{C}_{14} \mathrm{H}_{15} \mathrm{~N}_{2} \mathrm{O}_{3}: 259.1083$. Found: 259.1082.

4.4.3. Lactam 15: To a solution of $14(18.1 \mathrm{mg}, 70.2 \mu \mathrm{mol})$ and $\mathrm{CoCl}_{2} \cdot 6 \mathrm{H}_{2} \mathrm{O}(33.3 \mathrm{mg}, 140 \mu \mathrm{mol})$ in $\mathrm{MeOH}(3 \mathrm{~mL})$ was added $\mathrm{NaBH}_{4}(20.8 \mathrm{mg}, 550 \mu \mathrm{mol})$ in five portions over $2 \mathrm{~h}$. After stirring for $15 \mathrm{~min}$, $10 \% \mathrm{w} / \mathrm{v} \mathrm{KOH}$ in $\mathrm{MeOH}$ solution $(1 \mathrm{~mL})$ was added. After stirring for $3 \mathrm{~h}, 1 \mathrm{M} \mathrm{HCl}$ and brine were added, and the mixture was extracted with $\mathrm{CHCl}_{3}$. The combined extracts were washed with saturated aqueous $\mathrm{NaHCO}_{3}$ and brine, dried over $\mathrm{MgSO}_{4}$, filtered, and concentrated under reduced pressure. The residue was purified by silica gel column chromatography $\left(\mathrm{CHCl}_{3} / \mathrm{MeOH}=97 / 3 \rightarrow 95 / 5\right)$ to give $15(7.8$ mg, 48\%); mp 198.9-199.2 ${ }^{\circ} \mathrm{C} ;{ }^{1} \mathrm{H}$ NMR (400 MHz, $\mathrm{CDCl}_{3}$, $)$ ); 7.34 (dd, $1 \mathrm{H}, J_{1}=7.8 \mathrm{~Hz}, J_{2}=7.5 \mathrm{~Hz}$ ), $7.27(\mathrm{~d}, 1 \mathrm{H}, J=7.1 \mathrm{~Hz}), 7.10\left(\mathrm{dd}, 1 \mathrm{H}, J_{1}=7.5 \mathrm{~Hz}, J_{2}=7.6 \mathrm{~Hz}\right), 6.91$ (d, 1H, J=7.6 Hz), 6.39 (br, 1H), 3.75-3.69 (m, 1H), 3.64-3.57 (m, 1H), $3.25(\mathrm{~s}, 3 \mathrm{H}), 2.82(\mathrm{~d}, 1 \mathrm{H}, J=17.6 \mathrm{~Hz}), 2.37(\mathrm{~d}, 1 \mathrm{H}, J=17.7 \mathrm{~Hz})$, 2.24-2.17 (m, 1H), 1.82-1.76 (m, 1H); ${ }^{13} \mathrm{CNMR}\left(100 \mathrm{MHz}, \mathrm{CDCl}_{3}, \delta\right) ; 178.3,170.3,143.0,131.7,129.0$, 123.6, 123.2, 108.8, 46.1, 38.7, 37.7, 29.5, 26.6; IR (KBr) 3179, 1709, $1659 \mathrm{~cm}^{-1}$; HRMS $\left(\mathrm{M}+\mathrm{H}^{+}\right) \mathrm{Calcd}$ for $\mathrm{C}_{13} \mathrm{H}_{15} \mathrm{~N}_{2} \mathrm{O}_{2}$ : 231.1134. Found: 231.1129 .

\subsection{Synthesis of Pyrroloindole 17}

4.5.1. Carbamate 16: To a solution of $(S)-2 a(81 \%$ ee) $(326 \mathrm{mg}, 1.81 \mathrm{mmol})$ in $\mathrm{MeOH}(18 \mathrm{~mL})$ was added $\mathrm{CoCl}_{2} \cdot 6 \mathrm{H}_{2} \mathrm{O}(702 \mathrm{mg}, 2.95 \mathrm{mmol})$ at $0{ }^{\circ} \mathrm{C}$, and the mixture was stirred for $15 \mathrm{~min}$ at the same temperature. $\mathrm{NaBH}_{4}(342 \mathrm{mg}, 9.05 \mathrm{mmol})$ was added and stirring was continued at room temperature for $2 \mathrm{~h}$. After adding $2 \mathrm{M} \mathrm{HCl}$ at $0{ }^{\circ} \mathrm{C}$ and neutralizing with saturated aqueous $\mathrm{NaHCO}_{3}$, the mixture was extracted with EtOAc. The combined organic extracts were washed with saturated aqueous potassium sodium tartrate, dried over $\mathrm{Na}_{2} \mathrm{SO}_{4}$, filtered, and concentrated under reduced pressure. To a solution of the 
residue in pyridine $(10 \mathrm{~mL})$ was added 4 -( $N, N$-dimethylamino $)$ pyridine $(12.5 \mathrm{mg}, 0.102 \mathrm{mmol})$ and methylchloroformate $(0.40 \mathrm{~mL}, 5.1 \mathrm{mmol})$ at $0{ }^{\circ} \mathrm{C}$. After stirring at room temperature overnight, saturated aqueous $\mathrm{NH}_{4} \mathrm{Cl}$ was added, and the mixture was extracted with EtOAc. The combined organic extracts were dried over $\mathrm{Na}_{2} \mathrm{SO}_{4}$, filtered, and concentrated under reduced pressure. The residue obtained was purified by silica gel column chromatography (hexane/EtOAc $=9 / 1 \rightarrow 7 / 3)$ to give carbamate $16(182 \mathrm{mg}$, $53 \%$ over 2 steps) as a colorless oil: ${ }^{1} \mathrm{H}$ NMR $\left(400 \mathrm{MHz}, \mathrm{CDCl}_{3}, \delta\right) 7.33-7.20(\mathrm{~m}, 6 \mathrm{H}), 7.15$ (ddd, $1 \mathrm{H}, J_{1}$ $\left.=1.2 \mathrm{~Hz}, J_{2}=J_{3}=7.8 \mathrm{~Hz}\right), 7.04\left(\mathrm{ddd}, 1 \mathrm{H}, J_{1}=1.2 \mathrm{~Hz}, J_{2}=J_{3}=7.8 \mathrm{~Hz}\right), 6.74(\mathrm{~d}, 1 \mathrm{H}, J=7.8 \mathrm{~Hz}), 4.95(\mathrm{~d}$, $1 \mathrm{H}, J=15.8 \mathrm{~Hz}), 4.87$ (d, 1H, $J=15.8 \mathrm{~Hz}), 4.85(\mathrm{br}, 1 \mathrm{H}), 3.58(\mathrm{~s}, 3 \mathrm{H}), 3.02-2.91(\mathrm{~m}, 2 \mathrm{H}), 2.21-2.14(\mathrm{~m}$, 1H), 2.10-2.03 (m, 1H), 1.42 (s, 3H); ${ }^{13} \mathrm{C}$ NMR (100 MHz, $\left.\mathrm{CDCl}_{3}, \delta\right)$ 180.7, 157.0, 142.2, 136.1, 133.5, 129.0, 128.2, 127.8, 127.4, 123.0, 122.9, 109.4, 52.0, 47.1, 43.8, 37.7, 37.5, 24.4; IR $\left(\mathrm{CHCl}_{3}\right)$ 1708, 1611 $\mathrm{cm}^{-1}$; MS (FAB) $m / z=339\left(\mathrm{M}+\mathrm{H}^{+}\right)$.

4.5.2. Pyrroloindole 17: To solution of carbamate $16(52.1 \mathrm{mg}, 0.154 \mathrm{mmol})$ in THF was added $\mathrm{LiAlH}_{4}$ $(36.5 \mathrm{mg}, 0.770 \mathrm{mmol})$ at $0{ }^{\circ} \mathrm{C}$. After stirring at room temperature for $1.5 \mathrm{~h}$ and at reflux for $10 \mathrm{~min}$, $\mathrm{Na}_{2} \mathrm{SO}_{4} \cdot 10 \mathrm{H}_{2} \mathrm{O}$ was added at $0{ }^{\circ} \mathrm{C}$. After stirring for $1 \mathrm{~h}$ at room temperature, the inorganic solid was removed by filtration. The filtrate was dried over $\mathrm{Na}_{2} \mathrm{SO}_{4}$, filtered, and concentrated under reduced pressure. The residue obtained was purified by silica gel column chromatography $\left(\mathrm{CHCl}_{3} / \mathrm{MeOH}=95 / 5\right)$ to give pyrroloindole $17(18.3 \mathrm{mg}, 43 \%)$ as a colorless oil. Spectra were identical to those reported previously ${ }^{[46]} ;[\alpha]^{26}{ }_{D}-68\left(c=0.20\right.$ in $\left.\mathrm{CH}_{2} \mathrm{Cl}_{2}\right)$.

\section{Acknowledgements}

This work was supported in part by Grants-in-Aid for Scientific Research B (Y.T.) and for Young Scientists B (Y.Y.), Scientific Research on Priority Areas: Creation of Biologically Functional Molecules, and "Targeted Proteins Research Program" from the Ministry of Education, Culture, Sports, Science and Technology of Japan, and the 21st Century COE Program "Knowledge Information Infrastructure for Genome Science".

\section{References and notes}

1. For a review, see: (a) Galliford, C. V.; Sheidt, K. A. Angew. Chem. Int. Ed. 2007, 46, 8748. For recent examples, see: (b) Kolackowski, M.; Nowak, M.; Pawlowski, M.; Bojarski, A. J. J. Med. Chem. 2006, 49, 6732. (c) Kato, H.; Yoshida, T.; Tokue, T.; Nojiri, Y.; Hirota, H.; Ohta, T.; Williams, R. M.; Tsukamoto, S. Angew. Chem. Int. Ed. 2007, 46, 2254. (d) Uddin, M. K.; Reignier, S. G.; Coulter, T.; Montalbetti, C.; Grånäs, C.; Butcher, S.; Krog-Jensen, C.; Felding, J. Bioorg. Med. Chem. Lett. 2007, 17, 2854. (e) Stevens, F. C.; Bloomquist, W. E.; Borel, A. G.; Cohen, M. L.; Droste, C. A.; Heiman, M. L.; Kriauciunas, A.; Sall, D. J.; Tinsley, D. F. C.; Jesudason, C. D. Bioorg. Med. Chem. Lett. 2007, 17,6270 . 
2. (a) Ashimori, A.; Matsuura, T.; Overman, L. E.; Poon, D. J. J. Org. Chem. 1993, 58, 6949. (b) Ashimori, A.; Bachand, B.; Calter, M. A.; Govek, S. P.; Overman, L. E.; Poon, D,. J. J. Am. Chem. Soc. 1998, 120, 6488. (c) Overman, L. E.; Watson, D. A. J. Org. Chem. 2006, 71, 2587. (d) McDermott, M. C.; Stephenson, G. R.; Walkington, A. J. Synlett 2007, 51.

3. Pinto, A.; Jia, Y.; Neuville, L.; Zhu, J. Chem. Eur. J. 2007, 13, 961.

4. (a) Lee, S.; Hartwig, J. F. J. Org. Chem. 2001, 66, 3402. (b) Glorius, F.; Altenhoff, G.; Goddard, R.; Lehmann, C. Chem. Commun. 2002, 2704. (c) Arao, T.; Kondo, K.; Aoyama, T. Tetrahedron Lett. 2006, 47, 1417. (d) Kündig, E. P.; Seidel, T. M.; Jia, Y.; Bernardinelli, G. Angew. Chem. Int. Ed. 2007, 46,8484 .

5. (a) Shaw, S. A.; Aleman, P.; Vedejs, E. J. Am. Chem. Soc. 2003, 125, 13368.(b) Hills, I. D.; Fu, G. C. Angew. Chem. Int. Ed. 2003, 42, 3921. (c) Shaw, S. A;. Aleman, P.; Christy, J.; Kampf, J. W.; Va, P.; Vedejs, E. J. Am. Chem. Soc. 2006, 128, 925. (d) Duffey, T. A.; Shaw, S. A.; Vedejs, E. J. Am. Chem. Soc. 2009, 131, 14 .

6. (a) Trost, B. M.; Frederiksen, M. U. Angew. Chem. Int. Ed. 2005, 44, 308. (b) Trost, B. M.; Quancard, J. J. Am. Chem. Soc. 2006, 128, 6314. (c) Trost, B. M.; Brennan, M. K. Org. Lett. 2006, 8, 2027. (d) Trost, B. M.; Zhang, Y. J. Am. Chem. Soc. 2007, 129, 14548.

7. Trost, B. M.; Cramer, N.; Bernsmann, H. J. Am. Chem. Soc. 2007, 129, 3086.

8. Ogawa, S.; Shibata, N.; Inagaki, J.; Nakamura, S.; Toru, T.; Shiro, M. Angew. Chem. Int. Ed. 2007, 46, 8666.

9. Taylor, A. M.; Altman, R. A.; Buchwald, S. L. J. Am. Chem. Soc. 2009, 131, 9900.

10. (a) Tian, X.; Jiang, K.; Peng, J.; Du, W.; Chen, Y.-C. Org. Lett. 2008, 10, 3583. (b) Cheng, L.; Liu, L.; Jia, H.; Wang, D.; Chen, Y.-J. J. Org. Chem. 2009, 74, 4650.

11. Linton, E. C.; Kozlowski, M. C. J. Am. Chem. Soc. 2008, 130, 16162.

12. Additionally, lipase-catalyzed desymmetrization of 3,3-bis(hydroxymethyl)oxindole has also been reported; see: Akai, S.; Tsujino, T.; Akiyama, E.; Tanimoto, K.; Naka, T.; Kita, Y. J. Org. Chem. 2004, 69, 2478.

13. For a review, see. Yasui, Y.; Takemoto, Y. Chem. Rec. 2008, 8, 386.

14. Kobayashi, Y.; Kamisaki, H.; Yanada, K.; Yanada, R.; Takemoto, Y. Tetrahedron Lett. 2005, 46, 7549.

15. (a) Kobayashi, Y.; Kamisaki, H.; Yanada, R.; Takemoto, Y. Org. Lett. 2006, 8, 2711. (b) Kobayashi, Y.; Kamisaki, H.; Takeda, H.; Yasui, Y.; Yanada, R.; Takemoto, Y. Tetrahedron 2007, 63, 2978.

16. Yasui, Y.; Takeda, H.; Takemoto, Y. Chem. Pharm. Bull. 2008, 56, 1567.

17. Part of this work was published as a communication, see: Yasui, Y.; Kamisaki, H.; Takemoto, Y. Org. Lett. 2008, 10, 3303.

18. For a review, see: Nájera, C.; Sansano, J. M. Angew. Chem. Int. Ed. 2009, 48, 2452. 
19. (a) Nishihara, Y.; Inoue, Y.; Itazaki, M.; Takagi, K. Org. Lett. 2005, 7, 2639. (b) Nishihara, Y.; Inoue, Y.; Izawa, S..; Miyasaka, M.; Tanemura, K.; Nakajima, K.; Takagi, K. Tetrahedron 2006, 62, 9832.

20. (a) Nakao, Y.; Hirata, Y.; Hiyama, T. J. Am. Chem. Soc. 2006, 128, 7420. (b) Hirata, Y.; Inui, T.; Nakao, Y.; Hiyama, T. J. Am. Chem. Soc. 2009, 131, 6624.

21. (a) Nakao, Y.; Oda, S.; Hiyama, T. J. Am. Chem. Soc. 2004, 126, 13904. (b) Nakao, Y.; Yada, A.; Satoh, J.; Ebata, S.; Oda, S.; Hiyama, T. Chem. Lett. 2006, 35, 790. (c) Nakao, Y.; Oda, S.; Yada, A.; Hiyama, T. Tetrahedron 2006, 62, 7567. (d) Nakao, Y.; Yada, A.; Ebata, S.; Hiyama, T. J. Am. Chem. Soc. 2007, 129, 2428. (e) Nakao, Y;. Hirata, Y.; Tanaka, M.; Hiyama, T. Angew. Chem. Int. Ed. 2008, 47,385 .

22. Hirata, Y.; Tanaka, M.; Yada, A.; Nakao, Y.; Hiyama, T. Tetrahedron 2009, 65, 5037.

23. Nakao, Y.; Yukawa, T.; Hirata, Y.; Oda, S.; Satoh, J.; Hiyama, T. J. Am. Chem. Soc. 2006, 128, 7116. 24. (a) Watson, M. P.; Jacobsen, E. N. J. Am. Chem. Soc. 2008, 130, 12594. (b) Nakao, Y.; Ebata, S.;

Yada, A.; Hiyama, T.; Ikawa, M.; Ogoshi, S. J. Am. Chem. Soc. 2008, 130, 12874.

25. For general reactivity of cyanoformamides, see: (a) Oku, A.; Inoue, J.; Ueda, H.; Mashio, F. Bull.

Chem. Soc. Jpn. 1977, 50, 549, and references cited therein. (b) Ford, R. E.; Knowles, P.; Lunt, E.;

Marshall, S. M.; Penrose, A. J.; Ramsden, C. A.; Summers, A. J. H.; Walker, J. L.; Wright, D. E. J. Med. Chem. 1986, 29, 538.

26. Netherton, M. R.; Fu, G. C. Org. Lett. 2001, 3, 4295.

27. Yasui, Y.; Kinugawa, T.; Takemoto, Y. Chem. Commun. 2009, 4275.

28. (a) Nakatsuka, S.; Asano, O.; Goto, T. Heterocycles 1986, 24, 2791. (b) van Henegouwen, W. G. B.;

Fieseler, R. M.; Rutjes, F. P. J. T.; Hiemstra, H. J. Org. Chem. 2000, 65, 8317.

29. See supplementary material of ref 27.

30. For example, see: Yu, J.-Q.; Giri, R.; Chen, X. Org. Biomol. Chem. 2006, 4, 4041.

31. Morrison, J. D.; Burnett, R. E.; Agular, A. M.; Morrow, C. J.; Phillips, C. J. Am. Chem. Soc. 1971, 93, 1301.

32. Uozumi, Y.; Hayashi, T. J. Am. Chem. Soc. 1991, 113, 9887.

33. Tani, K.; Yamagata, T.; Nagata, K. Acta Crystallogr. 1994, C50, 1274.

34. Alexakis, A.; Mutti, S.; Formant, J. F. J. Am. Chem. Soc. 1991, 113, 6332.

35. Hulst, R.; de Vries, N. K.; Feringa, B. L. Tetrahedron: Asymmetry 1994, 5, 699.

36. de Vries, A. H. M.; Meetsma, A.; Feringa, B. L. Angew. Chem., Int. Ed. 1996, 35, 2374.

37. Badalassi, F.; Crotti, P.; Macchia, F.; Pineschi, M.; Arnold, A.; Feringa, B. L. Tetrahedron Lett. 1998, $39,7795$.

38. Alexakis, A.; Rosset, S.; Allamand, J.; March, S.; Guillen, F.; Benhaim, C. Synlett 2001, 1375.

39. Zhu, S.-F.; Fu, Y.; Xie, J.-H.; Liu, B.; Xing, L.; Zhou, Q.-L. Tetrahedron: Asymmetry 2003, 14, 3219.

40. Keller, E.; Maurer, J.; Naasz, R.; Schader, T.; Meetsma, A.; Feringa, B. L. Tetrahedron: Asymmetry 1998, 9, 2409. 
41. Kagan, H. B.; Dang, T.-P. J. Am. Chem. Soc. 1972, 94, 6429.

42. Hayashi, T.; Mise, T.; Kumada, M. Tetrahedron Lett. 1976, 48, 4351.

43. After these optimizations, further examinations on optically active ligands were attempted, which ended up with a conclusion that $\mathbf{L 8}$ gives the best selectivity. See Supplementary Content.

44. (a) Satoh, T.; Suzuki, S.; Suzuki, Y.; Miyaji, Y.; Imai, Z. Tetrahedron Lett. 1969, 10, 4555. (b) Heinzman, S. W.; Ganem, B. J. Am. Chem. Soc. 1982, 104, 6801. (c) Williams, J. P.; Laurent, D. R. St.; Friedrich, D.; Pinard, E.; Roden, B. A.; Paquette, L. A. J. Am. Chem. Soc. 1994, 116, 4689.

45. Yu, Q.-S.; Brossi, A. Heterocycles 1988, 27, 1709.

46. Huang, A.; Kodanko, J. J.; Overman, L. E. J. Am. Chem. Soc. 2004, 126, 14043.

47. Coulson, D. R. Inorg. Synth. 1972, 13, 121.

48. Rimkus, A.; Sewald, N. Org. Lett. 2003, 5, 79.

49. See Supplementary Content for the syntheses of other cyanoformamides. 